\title{
Multi-objective optimization of organic Rankine cycles for waste heat recovery: Application in an offshore platform
}

Pierobon, Leonardo; Nguyen, Tuong-Van; Larsen, Ulrik; Haglind, Fredrik; Elmegaard, Brian

Published in:

Energy

Link to article, DOI:

10.1016/j.energy.2013.05.039

Publication date:

2013

Link back to DTU Orbit

Citation (APA):

Pierobon, L., Nguyen, T-V., Larsen, U., Haglind, F., \& Elmegaard, B. (2013). Multi-objective optimization of organic Rankine cycles for waste heat recovery: Application in an offshore platform. Energy, 58, 538-549. https://doi.org/10.1016/j.energy.2013.05.039

\section{General rights}

Copyright and moral rights for the publications made accessible in the public portal are retained by the authors and/or other copyright owners and it is a condition of accessing publications that users recognise and abide by the legal requirements associated with these rights.

- Users may download and print one copy of any publication from the public portal for the purpose of private study or research.

- You may not further distribute the material or use it for any profit-making activity or commercial gain

- You may freely distribute the URL identifying the publication in the public portal 


\title{
Multi-objective optimization of organic Rankine cycles for waste heat recovery: Application in an offshore platform
}

\author{
Leonardo Pierobon*, Tuong-Van Nguyen, Ulrik Larsen, Fredrik Haglind, Brian Elmegaard \\ Technical University of Denmark, Department of Mechanical Engineering,
}

Building 403, DK-2800 Kgs. Lyngby, Denmark

\begin{abstract}
This paper aims at finding the optimal design of MW-size organic Rankine cycles by employing the multiobjective optimization with the genetic algorithm as the optimizer. We consider three objective functions: thermal efficiency, total volume of the system and net present value. The optimization variables are the working fluid, the turbine inlet pressure and temperature, the condensing temperature, the pinch points and the fluid velocities in the heat exchangers. The optimization process also includes the complete design of the shell and tube heat exchangers utilized in the organic Rankine cycle. The methodology is applied to recover the waste heat from the SGT-500 gas turbine installed on the Draugen off-shore oil and gas platform in the North Sea. Results suggest two optimal working fluids, i.e. acetone and cyclopentane. Thermal efficiency and net present value are higher for cyclopentane than for acetone. Other promising working fluids are cyclohexane, hexane and isohexane. The present methodology can be utilized in waste heat recovery applications where a compromise between performance, compactness and economic revenue is required.
\end{abstract}

\footnotetext{
* Corresponding author. Tel.: +45 452541 29; fax: +45 45884325 .

E-mail address: lpier@mek.dtu.dk (L. Pierobon)
} 
Keywords: Organic Rankine cycle; Multi-objective optimization; Shell and tube heat exchanger; Off-shore platform; Gas turbine

\section{Introduction}

In March 2007 the Commission of the European Communities [1] set the "20-20-20” targets as the three key objectives for 2020. The requirements are, namely, a 20\% reduction in greenhouse gas emission from the 1990 levels, a $20 \%$ share of renewable sources in the energy demand and a 20\% improvement in the energy efficiency. De Paepe [2] considers the annual recoverable industrial waste heat potential to be about 140 TWh in Europe, corresponding to a $\mathrm{CO}_{2}$ reduction of about $14 \mathrm{Mt} / \mathrm{y}$. As surveyed by Colonna [3], this waste heat is available at high $\left(350-250{ }^{\circ} \mathrm{C}\right)$, medium $\left(250-150^{\circ} \mathrm{C}\right)$ and low temperatures $\left(150-90^{\circ} \mathrm{C}\right)$ and the power capacity may range from large to small in size (15 MW to $3 \mathrm{~kW}$ ). With increasing incentives for reducing the $\mathrm{CO}_{2}$ emissions offshore, waste heat recovery on off-shore platforms has become a focus area. In off-shore applications, the key selection criteria for the waste heat recovery unit supporting the electrical demand on the platform are high efficiency, fuel flexibility, compactness and low weight.

Single and dual-pressure steam Rankine cycles are established and reliable solutions for high-temperature waste heat recovery as discussed, for example, in Gewald et al. [4], Rokni [5] and Domingues et al. [6]. However, the moisture content at the turbine outlet and the limits on the turbine blade height in practice restrict the application to MW-size power units. The organic Rankine cycle (ORC) is a technology that is receiving more and more attention from the academic world, companies and research institutes. Major ORC advantages are the simplicity of the cycle and the possibility of tailoring the working fluid to the specific temperature profile of the heat source. Furthermore, the ORC eliminates the problem of turbine blade erosion due to the liquid droplet formation by utilizing a "dry” fluid as the working fluid. Vélez et al. [7] provide an ample review of existing and possible applications of the ORC technology. A crucial aspect in the design of an ORC is the selection of the 
working fluid. Moreover, the thermal efficiency, compactness, weight, availability and cost are among the most important concerns of a complete design process. Additionally, the operating fluid should be chemically stable, environmentally friendly and safe in terms of toxicity and flammability. As emphasized in Velez et al. [7], no fluid satisfies all these aspects; therefore, the selection is a compromise between the different possibilities.

In the past, much research was conducted to develop optimization algorithms to adapt the ORC to the specific heat source and to address different objectives. Sun and Li [8] implement the ROSENB optimization algorithm to search the optimal set of operating variables to maximize either the system net power generation or the system thermal efficiency. Roy et al. [9] carry out a parametric optimization and performance analysis of an organic Rankine cycle where the heat source is the flue gas at a temperature of $140{ }^{\circ} \mathrm{C}$ exiting the discharged fans of a coal power plant. Hettiarachchi et al. [10] use as the objective function the ratio of total heat exchange area to net power output. Quoilin et al. [11] optimize a small-scale ORC for waste heat recovery applications; economic profitability and thermodynamic efficiency are the objective functions. Baik et al. [12] employ the pattern search algorithm to maximize the net power output considering the overall heat transfer conductance and turbine inlet pressure and temperature as optimization variables. In Wang et al. [13] and in Dai et al. [14], the genetic algorithm (GA) is used as the optimization method for a comparative study of ORCs for low-temperature waste heat recovery. Cayer et al. [15] present a parametric study of a $\mathrm{CO}_{2}$ supercritical power cycle using six performance indicators: thermal efficiency, specific net output, exergetic efficiency, total UA and surface of the heat exchangers, and the relative cost of the system. The concept is extended by Shengjun et al. [16] to subcritical and supercritical ORCs minimizing the levelized energy cost and heat exchanger area per unit power output. Salcedo et al. [17] apply the multi-objective optimization to solar Rankine cycles coupled with reverse osmosis desalination considering the specific total cost and the environmental impact of the plant. Wang et al. [18] perform a parametric optimization using a multi-objective optimization to design ORCs for low temperature waste heat. The screening criteria include heat exchanger area per unit power output and heat recovery efficiency. 
The present paper aims at presenting a generic methodology to design and optimize ORCs where shell and tube heat exchangers are used. In order to assess the compactness of the system, a detailed dimensioning of the shell and tube heat exchanger is carried out considering both the heat transfer coefficients and the pressure drops on the shell and tube sides. We use a multi-objective optimization modeled by the genetic algorithm using the following objective functions: thermal efficiency, total volume of the ORC and net present value. We apply the methodology to recuperate the waste heat from the SGT-500 gas turbine installed on the Draugen platform (Kristiansund, The North Sea). Compared with previous works [8-18], the approach in this paper is novel in the sense that it includes the total volume of the organic Rankine cycle and the net present value as objective functions. Furthermore, in contrast to previous works, the geometry of the shell-and-tube heat exchanger is included in the optimization procedure. The novel set of optimization variables includes 109 working fluids, turbine inlet pressure and temperature, pinch points of condenser, internal recuperator and evaporator/economizer and fluid velocities in the tubes and on the shell side, respectively, of all heat exchangers. Other characteristics of the working fluids, such as health, fire and physical hazards [19], and the global warming potential (GWP) are, to some extent, also considered. The methodology presented in this paper can be applied in waste heat recovery applications where the ORC design is the result of a compromise between performance, compactness and economic revenue.

We describe the shell and tube design process, the ORC's governing equations and the multi-objective optimization in section 2. The case study is also presented in section 2. Results of the multi-objective optimization are reported in section 3 and discussed in detail in section 4. Finally, we state the main conclusions in section 5 .

\section{Methodology}


We outline the features and details of the new methodology in this section. The modeling of shell and tube heat exchangers is described introducing the equations computing the heat transfer coefficients, the geometry and the investment cost. In subsection 2.2, we present the modeling of the other ORC components. The heat transfer fluid, Dowtherm Q, is introduced in subsection 2.3. Finally, subsections 2.4 and 2.5 introduce the multi-objective optimization and the case study where the methodology is applied.

\subsection{Shell and tube heat exchangers}

The basic design procedure requires determining the surface area that is needed using the available temperature difference. The governing equation for the heat transfer across a surface is

$\dot{Q}=U A F_{t} \Delta T_{l m}$

where $\dot{Q}$ is the heat rate, $U$ is the overall heat transfer coefficient, $A$ is the heat transfer area, $\Delta T_{l m}$ is the logarithm mean temperature difference and $F_{t}$ is the temperature correction factor which accounts for co-current and cross-flow. We compute the correction factor in Eq. (1) utilizing the method proposed by Fakheri [20]. The overall heat transfer coefficient can be regarded as the sum of the following five different items: the outside fluid film coefficient $h_{o}$, the inside fluid film coefficient $h_{i}$, the outside dirt coefficient (fouling factor) $h_{o d}$, the inside dirt coefficient $h_{i d}$ and the thermal conductivity of the tube wall material $\lambda_{w}$. The overall coefficient based on the outside area of the tube can be calculated as follows:

$\frac{1}{U_{o}}=\frac{1}{h_{o}}+\frac{1}{h_{o d}}+\frac{d_{0} \ln \frac{d_{0}}{d_{i}}}{2 \lambda_{w}}+\frac{d_{0}}{d_{i}} \frac{1}{h_{i d}}+\frac{d_{0}}{d_{i}} \frac{1}{h_{i}}$

where $d_{0}$ and $d_{i}$ are the outer and inner diameter of the tubes. 

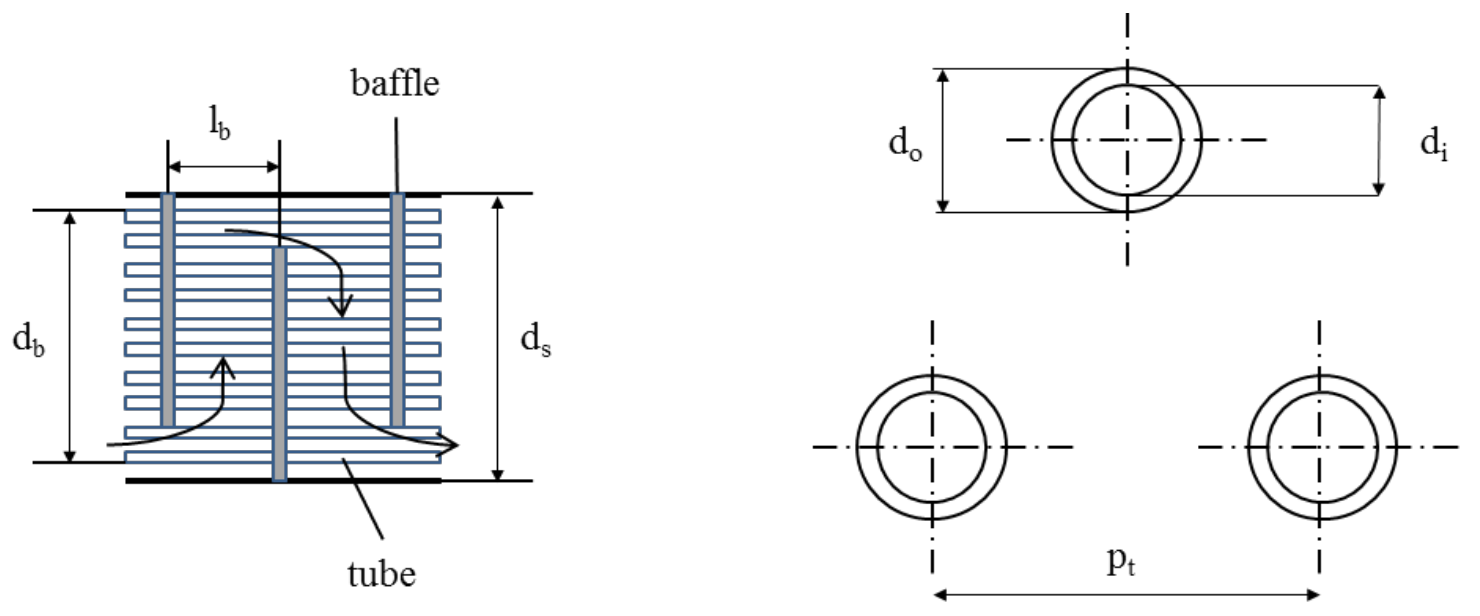

Figure 1. Shell and tube heat exchanger geometry and tube pattern.

Fig. 1 shows the generic geometry of the shell and tube heat exchanger. The geometrical parameters considered in the design are the following: the inner and outer diameters of the tubes, the tube length $l_{t}$, the distance between the tube centers (pitch) $p_{t}$, the number of tube passes $N_{t}$ and the baffle spacing $l_{b}$. Based on the well-established design procedure outlined in Richardson and Peacock [21], the geometry of the heat exchanger and the fluid velocity in the tubes and on the shell side can be calculated. We evaluate the volume $V_{h t}$ of the shell and tube heat exchanger assuming a cylindrical shape:

$V_{h t}=F_{t s} \frac{\pi}{4} d_{s}^{2} l_{t}$

The shell diameter $d_{s}$ and the tube length are the diameter of the base and the height of the cylinder (see Eq. (3)). A correction factor $F_{t s}$ is applied to account for the space occupied by the shell and tube inlet and outlet ducts. As formulated in Hall [22], the purchased-equipment cost $P E C_{h t}$ is a function of the heat exchanger area $A$ and it can be computed as follows: 
$P E C_{h t}=10000+324 A^{0.91}$

The heat transfer coefficient $h_{t}$ and the pressure drop $\Delta p_{t}$ on the tube side in the subcooled liquid and superheated vapor regions are related the Reynolds number Re, Prandtl number $\operatorname{Pr}$ and velocity in the tubes $u_{t}$ and are evaluated using the following methodology [21]:

$h_{t}=j_{t h} \frac{\lambda_{t}}{d_{i}} \operatorname{Re} \operatorname{Pr}^{0.33}\left(\frac{\mu_{t}}{\mu_{t w}}\right)^{0.14}$

$\Delta p_{t}=N_{t}\left[8 j_{t f} \frac{l_{t}}{d_{i}}\left(\frac{\mu_{t}}{\mu_{t w}}\right)^{-m}+2.5\right] \frac{\rho_{t} u_{t}^{2}}{2}$

where $\rho_{t}, \lambda_{t}$ and $\mu_{t}$ are the density, the thermal conductivity and the dynamic viscosity calculated at the average temperature between the inlet and the outlet conditions of the tube; $\mu_{t w}$ is the dynamic viscosity of the fluid calculated at the temperature of the inner wall of the tube. The quantities $j_{t h}$ and $j_{t f}$ are the heat transfer and friction factor of the tubes and are evaluated as reported in [21]. The coefficient $m$ is equal to 0.25 for laminar flow $(\operatorname{Re}<2100)$ and 0.14 for turbulent flow $(\operatorname{Re}>2100)$. The following equation gives a more accurate estimate of the heat transfer coefficient of water, utilized as the cooling fluid in the condenser tubes [21]:

$h_{t}=\frac{4200(1.35+0.02 t) u_{t}^{0.8}}{d_{i}^{0.2}}$

where $t$ is the average temperature of the water in the tube. The calculation of the heat transfer coefficient on the shell side $h_{s}$ is based on the experimental work carried out by Kern [23] on commercial exchangers with standard tolerances. Richardson and Peacock [21] state that the methodology gives a satisfactory prediction of the heattransfer coefficient. The heat transfer coefficient $h_{s}$ and the pressure drop $\Delta p_{s}$ on the shell side in the subcooled 
liquid and superheated vapor regions are related to the Reynolds number Re, Prandtl number Pr and velocity on the shell side $u_{s}$ and are evaluated using the following methodology [21]:

$h_{s}=j_{s h} \frac{\lambda_{s}}{d_{e}} \operatorname{Re}^{\operatorname{Pr}^{1 / 3}}\left(\frac{\mu_{s}}{\mu_{s w}}\right)^{0.14}$

$\Delta p_{s}=8 j_{s f} \frac{d_{s}}{d_{e}} \frac{l_{t}}{l_{b}}\left(\frac{\mu_{s}}{\mu_{s w}}\right)^{-0.14} \frac{\rho_{s} u_{s}^{2}}{2}$

where $d_{e}, \rho_{s}, \lambda_{s}$ and $\mu_{s}$ are the equivalent shell diameter, the density, the thermal conductivity and viscosity calculated with the average temperature between the inlet and the outlet conditions of the shell; $\mu_{s w}$ is the viscosity of the fluid calculated with the temperature of the outer wall of the tube. The quantities $j_{s h}$ and $j_{s f}$ are the heat transfer and friction factor of the shell and are evaluated as reported in [21]. Assuming that the evaporator operates in the nucleate boiling region, we evaluate the heat transfer coefficient with the Cooper correlation [24]. The nucleate boiling heat transfer coefficient $h_{n b}$ is a function of the reduced pressure $p_{r}$, the molecular weight of the fluid $M$, the specific heat rate $\dot{Q} / A$ and the surface roughness $R_{p}$ (assumed to be $1 \mu \mathrm{m}$ [23]) and it can be expressed by mathematically as

$h_{n b}=55 p_{r}^{0.12-0.4343 \ln R_{p}}\left(-0.4343 \ln p_{r}\right)^{-0.55} M^{-0.5}\left(\frac{\dot{Q}}{A}\right)^{0.67}$

The pressure drops are evaluated as the average between the pressure drops calculated with the thermodynamic properties and the speed computed at the saturated liquid and saturated vapor states. In ORCs the heat rejection starts in the superheated region. Hence, the calculation of the heat transfer coefficient is split into two processes: de-superheating and condensation. Since it is assumed that the condensation takes place on the shell side, Eq. (8) 
is utilized. In the second step, assuming condensation outside the horizontal tubes, the following equations are utilized as suggested by Richardson and Peacock [21]:

$$
\begin{aligned}
& h_{\text {cond }}=0.95 \lambda_{l}\left[\frac{\rho_{l}\left(\rho_{l}-\rho_{g}\right) g}{\mu_{l} \Gamma}\right]^{1 / 3} \\
& \Gamma=\frac{\dot{m}}{N_{t} l_{t}}
\end{aligned}
$$

where $g$ is the standard gravity, $\Gamma$ is the tube loading and $\rho_{l}, \lambda_{l}, \mu_{l}$ are the density, thermal conductivity and dynamic viscosity at the saturated liquid state, while $\rho_{g}$ is the density at the saturated vapor condition. As suggested by Kern [23], the pressure drop on the condensing side is quantified as half of the pressure drop (Eq. (9)) based on the vapor inlet conditions.

\subsection{Organic Rankine cycle modeling}

As shown in Fig. 2, the ORC components are the turbine (TUR), connected through the shaft to the electric generator (GEN), the liquid pump and five different heat exchangers: economizer (ECO), evaporator (EVA), superheater (SUP), internal recuperator (IR) and condenser. Each component is modeled at steady state conditions. 


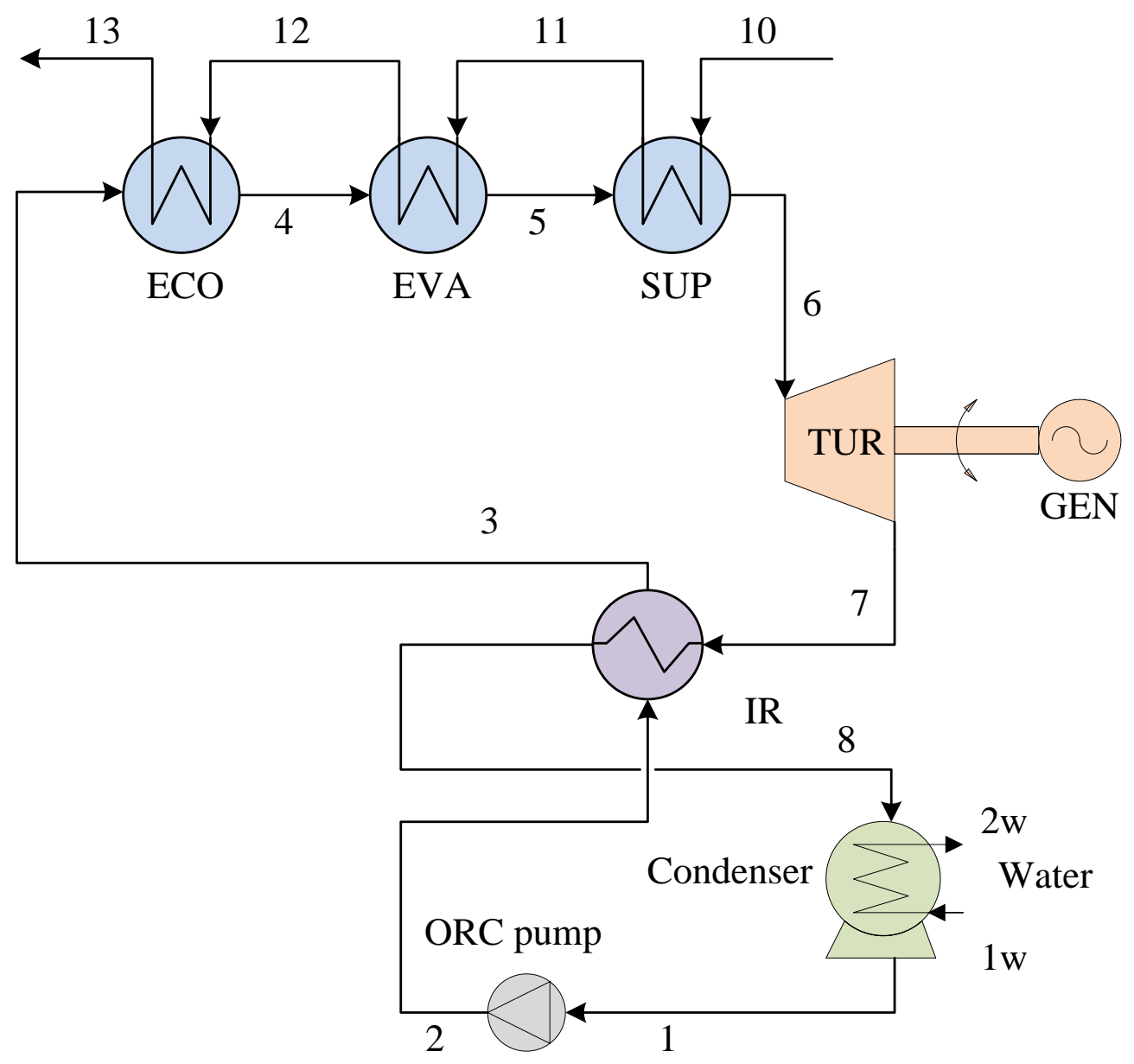

Figure 2. Organic Rankine cycle layout.

The outlet enthalpy $h_{2}$ and the power consumption $\dot{P}_{p}$ of the pump are calculated as follows:

$h_{2}=h_{1}+\frac{p_{2}-p_{1}}{\rho}$

$\dot{P}_{p}=\frac{\dot{m}\left(h_{2}-h_{1}\right)}{\eta_{m}}$ 
where $p_{1}$ and $p_{2}$ are the pressure at the inlet and at the outlet of the pump, $h_{1}$ is the inlet enthalpy, $\rho$ is the density of the working fluid, $\dot{m}$ is the mass flow circulating in the organic cycle and $\eta_{m}$ is the mechanical efficiency of the pump.

$P E C_{p}=422 \dot{P}_{p}^{0.71}\left[1.41+1.41\left(\frac{1-0.8}{1-\eta_{m}}\right)\right]$

The purchased-equipment cost $P E C_{p}$ is evaluated with Eq. (15) which was utilized by Arsalis et al. [25] for water pumps. The volume of the pump is considered negligible. The turbine is modeled by using the polytropic efficiency. The purchased-equipment cost of the turbine $P E C_{t u r}$ is assumed to be comparable with the purchase price of conventional steam axial turbines. In this paper we use the analytical expression proposed by Lian et al. [26] which depends on the power output $\dot{W}_{\text {tur }}$ :

$P E C_{\text {tur }}=6000 \dot{W}_{\text {tur }}{ }^{0.7}$

Since the methodology is applied to MW-size ORCs, it is assumed that the expander is an axial turbine with a unique stage (nozzle and rotor). As shown in Fig. 3, the volume $V_{t u r}$ is modeled as a cylindrical trapezoid. We evaluate the inlet and outlet flow areas $A_{\text {in }}$ and $A_{\text {out }}$ through the continuity equation considering an inlet Mach number of 0.3 [27]. The external inlet and outlet diameter $d_{i n, e}$ and $d_{\text {out }, e}$ are calculated assuming a tip to hub ratio of 1.43 [28] and an axial length $l_{x}$ of $0.3 \mathrm{~m}$. A correction factor $F_{t v}$ of 1.2 is applied to account for the space required by the inlet and outlet ducts and the electric generator. 


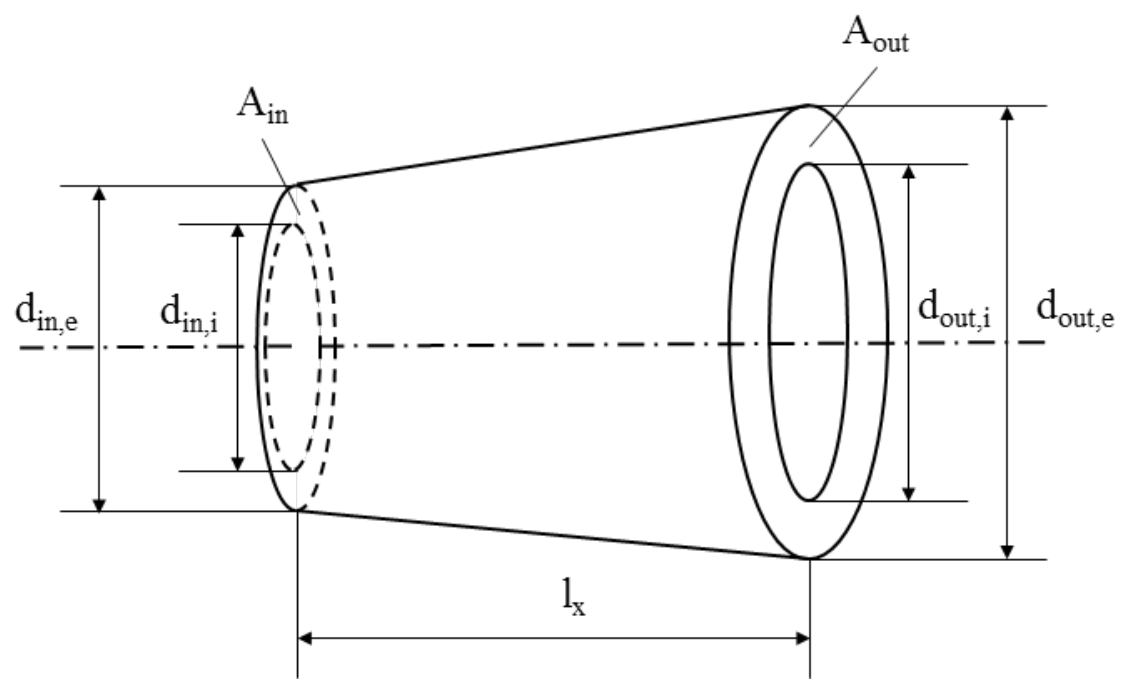

Figure 3. Geometric representation (cylindrical trapezoid) of the axial turbine in the organic Rankine cycle.

$V_{\text {tur }}=F_{\text {tv }}\left[\frac{\pi}{4}\left(d_{\text {out }, e^{2}}+d_{\text {in }, e}{ }^{2}\right)+\frac{\pi}{4} d_{\text {out }, e} d_{\text {in,e }}\right] \frac{l_{x}}{3}$

We calculate the electric power output $\dot{P}_{g e n}$ and the PEC of the electric generator $P E C_{g e n}$ as follows:

$\dot{P}_{\text {gen }}=\eta_{e l} \dot{W}_{t u r}$

$P E C_{g e n}=60 \dot{P}_{g e n}{ }^{0.95}$

where $\eta_{e l}$ is the electric efficiency of the generator. According to the previous equations, the net power output $\dot{P}_{n e t}$ and the thermal efficiency $\eta_{t h}$ of the ORC are defined as

$\dot{P}_{n e t}=\dot{P}_{g e n}-\dot{P}_{p}$ 
$\eta_{t h}=\frac{\dot{P}_{n e t}}{\dot{m}\left(h_{6}-h_{3}\right)}$

where $h_{6}$ and $h_{3}$ are the enthalpies at the outlet of the superheater and at the inlet of the economizer.

\subsection{Dowtherm $Q$ thermodynamic and physical properties}

The ORC working fluid is typically a carbon-based or hydrogen-based fluid, and the combustion products of a biomass plant or the exhaust gases exiting gas turbines, diesel and gas engines have high oxygen content. Hence, for safety reasons, an intermediate loop is placed between the ORC and the heat source. As suggested by Pierobon et al. [29], Dowtherm Q is selected as an intermediate heat carrier. We calculate the thermodynamic and physical properties by fitting the experimental data released by DOW Chemical Company [30] and assuming an incompressible liquid with a high density:

$\rho=1187-206.51 \frac{T}{273.15}$

$c_{p}=0.7702-0.8264 \frac{T}{273.15}$

$h=\int_{T_{0}}^{T} c_{p}(T) d T$

$\lambda=0.1651-0.0398 \frac{T}{273.15}$

$\mu=\exp \left[-4.053994+6.0844339 /\left(\frac{T}{273.15}\right)^{1.5}\right]$ 
where $c_{p}$ is the specific heat capacity at constant pressure and $T$ is the Dowtherm Q temperature in Kelvin.

\subsection{The multi-objective optimization}

A multi-objective optimization involves minimizing or maximizing simultaneously two or more functions subjected to a set of constraints. In contrast to single-objective optimization, a solution to a multi-objective problem is a range of optimal points, the so-called Pareto front [31]. We use the genetic algorithm [32] for the benefits of avoiding the calculation of derivatives and enabling the search of global optima. The genetic algorithm parameters are specified according to the following values: population size 1000, generation size 200, crossover fraction 0.8 and migration fraction 0.2 . These numerical values are selected in order to ensure the repeatability of the solution when different simulations are performed. The genetic algorithm stops when the maximum number of generations is reached or when the average change in the spread of the Pareto front is lower than the specified tolerance (which in this paper is $10^{-3}$ ). Fig. 4 shows the structure of the algorithm. As indicated in the figure, the multi-objective optimization governs a global routine developed in MATLAB 2012a. The thermodynamic properties of the ORC working fluid are acquired by linking MATLAB and the commercial software REFPROP 9 [33]. 


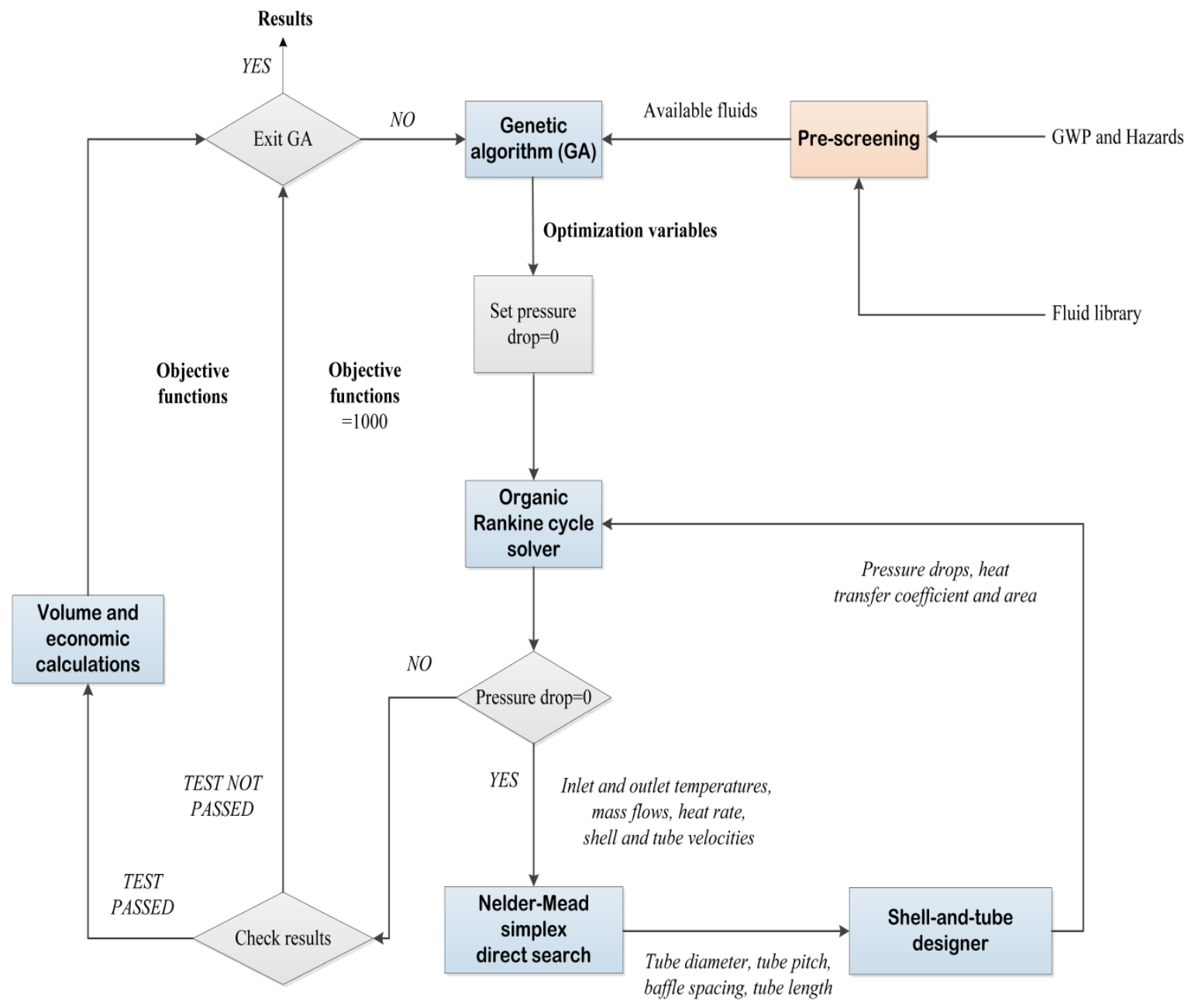

Figure 4. Structure of the multi-objective algorithm. The optimization routine involves the pre-screening process, the ORC solver, the Nelder-Mead direct search optimizer, the shell and tube designer, and the volume and economic evaluations.

First, in the pre-screening process the number of available working fluids is restricted by discarding the fluids for which the physical, health, fire hazard or GWP exceed the maximum allowable values set by the user. This is carried out by linking mathematically the working fluids to a unique integer number (from 1 to 109) corresponding to a specific fluid in REFPROP. Consequently, the algorithm can interpret and operate 
numerically on this optimization variable. The listed fluids, their GWPs in 100 years and their hazards, are taken from Pierobon et al. [34]. After this preliminary step, the optimization variables are passed to the GA. In the present paper the following variables (see Fig. 4) are optimized:
a) ORC working fluid
b) Condenser outlet temperature $T_{1}$
c) Condenser pinch point (located at the saturated vapor state)
d) Internal recuperator pinch point $T_{2}-T_{8}$
e) Minimum temperature difference (pinch point) in the economizer or vaporizer
f) Turbine inlet pressure $p_{6}$
g) Superheating temperature difference $T_{10}-T_{6}$
h) Target velocities in the tubes and on the shell side for each heat exchanger $u_{t t}, u_{s t}$

The ORC solver then acquires these values and computes the thermodynamic properties at each state, the thermal efficiency and the net power output. During the first run of the ORC solver, the pressure drops in the heat exchangers are set to zero. The solution is then utilized as the design condition for the heat exchangers and the expander. The heat rate, the mass flow, the inlet and outlet temperatures, and the fluid velocities in the tubes and on the shell side are passed to the shell and tube designer. At this point the constrained Nelder-Mead optimizer [35] is employed to select the tube and shell geometry that gives the specified velocity in the tubes and on the shell side. In order to reduce the computational time required by the sub-optimization, we use the tube length to obtain the specified velocity in the tubes; thereby, the function to be minimized can be expressed by the following equation:

$f\left(d_{o}, u_{t t}, p_{t}, l_{b}\right)=\frac{\left|u_{t s}-u_{s}\right|}{u_{t s}}$ 
where $\left|u_{t s}-u_{s}\right|$ is the absolute difference between the targeted shell speed $u_{t s}$ and the shell speed calculated in the shell and tube design process. Table 1 lists the lower and upper bounds of the geometric variables and the design parameters which are kept constant in the shell and tube heat exchanger design. If the heat transfer process occurs in the two-phase region, we employ an average velocity evaluated at the saturated liquid and saturated vapor condition.

Table 1. Lower and upper bounds of the geometric variables utilized in the shell and tube heat exchanger design process.

Variable

Outer diameter $d_{o}$ [21]

Tube pitch $p_{t}$ [36]

Baffle spacing $l_{b}$ [21]

\section{Parameters [21]}

Baffle cut $b_{c}$

Configuration

Outside dirt coefficient $h_{o d}$

Inside dirt coefficient $h_{i d}$

Thermal conductivity (tube wall)

Correction factor $F_{t s}$

\section{Lower bound Upper bound}

$16 \mathrm{~mm} \quad 50 \mathrm{~mm}$

$1.15 d_{0} \quad 2.25 d_{0}$

$0.2 d_{s} \quad 1.0 d_{s}$

\section{$25 \%$}

triangular

$6000 \mathrm{~W} /\left(\mathrm{m}^{2}{ }^{\circ} \mathrm{C}\right)$

$6000 \mathrm{~W} /\left(\mathrm{m}^{2}{ }^{\circ} \mathrm{C}\right)$

$50 \mathrm{~W} /\left(\mathrm{m}^{\circ} \mathrm{C}\right)$

1.2

The outcomes of the heat exchanger design are the overall heat transfer coefficient, the surface area, the volume and the pressure drops. The pressure drops are set as inputs to the ORC solver, and a new thermal efficiency and net power output are computed. We then check the consistency of the results. For each heat exchanger we verify 
that the value of the function, calculated with Eq. (27), is lower than the required accuracy, which we specify to be $10^{-2}$. Furthermore, in case the inlet temperature difference $T_{13}-T_{3}$ of the economizer or $T_{12}-T_{4}$ of the vaporizer is lower than the specified minimum temperature difference, we discard the solution. The three objective functions are expressed below. The function $f_{1}$ aims at maximizing the thermal efficiency. To increase the ORC compactness, the sum of the volumes of the ORC components is minimized (function $f_{2}$ ) and to analyze the profitability of the investment, the net present value is maximized (function $f_{3}$ ).

$f_{1}=-\eta_{t h}$

$f_{2}=V_{\text {eco }}+V_{\text {eva }}+V_{\text {sup }}+V_{I R}+V_{\text {cond }}+V_{\text {tur }}=V_{\text {tot }}$

$f_{3}=-N P V$

According to Bejan et al. [37], the $N P V$ can be calculated considering the equipment lifespan $n$, the interest factor $q$, the total capital investment $I_{T O T}$ and the annual income $R_{i}$ :

$N P V=\sum_{i=1}^{n} \frac{R_{i}}{(1+q)^{i}}-I_{T O T}$

The discounted payback period $D P B$ that estimates the time required to recover the principal amount of an investment is mathematically defined as the minimum year at which the $N P V$ is greater than zero:

$D P B=\min \{n: N P V(n)>0\}$ 
As suggested by Bejan et al. [37], the total investment cost of the ORC can be regarded by evaluating the direct and indirect costs.

Table 2. Estimate of total capital investment based on direct and indirect costs as suggested by Bejan et al. [37].

\section{Total capital investment}

\section{A. Direct costs}

1. Onsite costs

a) Purchased - equipment costs (PEC)

b) Purchased - equipment installation $\quad 45 \%$ PEC

c) Piping $35 \%$ PEC

d) Instrumentation + controls $20 \%$ PEC

e) Electrical equipment + materials $\quad 11 \% \mathrm{PEC}$

2. Offsite costs

f) Civil, structural + architectural work $30 \%$ PEC

g) Service facilities $50 \%$ PEC

\section{B. Indirect costs}

i) Engineering + supervision $\quad 8 \% \mathrm{DC}$

j) Construction costs + constructors profit $15 \% \mathrm{DC}$

k) Contingency $\quad 15 \%($ of $\mathrm{i}$ and $\mathrm{j}$ )

Using the values reported in Table 2, we calculate the total investment cost of the ORC as follows:

$I_{T O T}=3.7\left(P E C_{\text {tur }}+P E C_{e c o}+P E C_{\text {eva }}+P E C_{\text {sup }}+P E C_{I R}+P E C_{p}+P E C_{\text {cond }}+P E C_{\text {gen }}\right)$ 


\subsection{Case study - the Draugen platform}

We applied this methodology to recover the waste heat from the Siemens SGT-500 gas turbine employed on the Draugen off-shore platform, located 150 km from Kristiansund, in the Norwegian Sea. The platform, operated by A/S Norske Shell, produces gas and oil. Gas is exported via the Åsgard gas pipeline to Kårstø (Norway). Oil is first stored in storage cells at the bottom of the sea and then exported via a shuttle tanker (once every 1-2 weeks). The platform has three SGT-500 engines to provide the normal total electric load. The SGT-500 is an industrial twin-spool gas turbine, and the engine model is the C-version launched in the beginning of the 1980s. Table 3 reports the design point specifications of the SGT-500.

Table 3. Design point specifications for the Siemens SGT-500 twin-spool gas turbine [29].

\section{Model}

Siemens SGT-500

Turbine inlet temperature

$850{ }^{\circ} \mathrm{C}$

Exhaust gas temperature

$376^{\circ} \mathrm{C}$

Exhaust gas mass flow

$93.5 \mathrm{~kg} / \mathrm{s}$

Net power output

17.014 MW

Heat rate

11312 kJ/kWh

Fuel

Naphtha, crude oil, heavy fuel oil,

bio oil, natural gas, syngas 


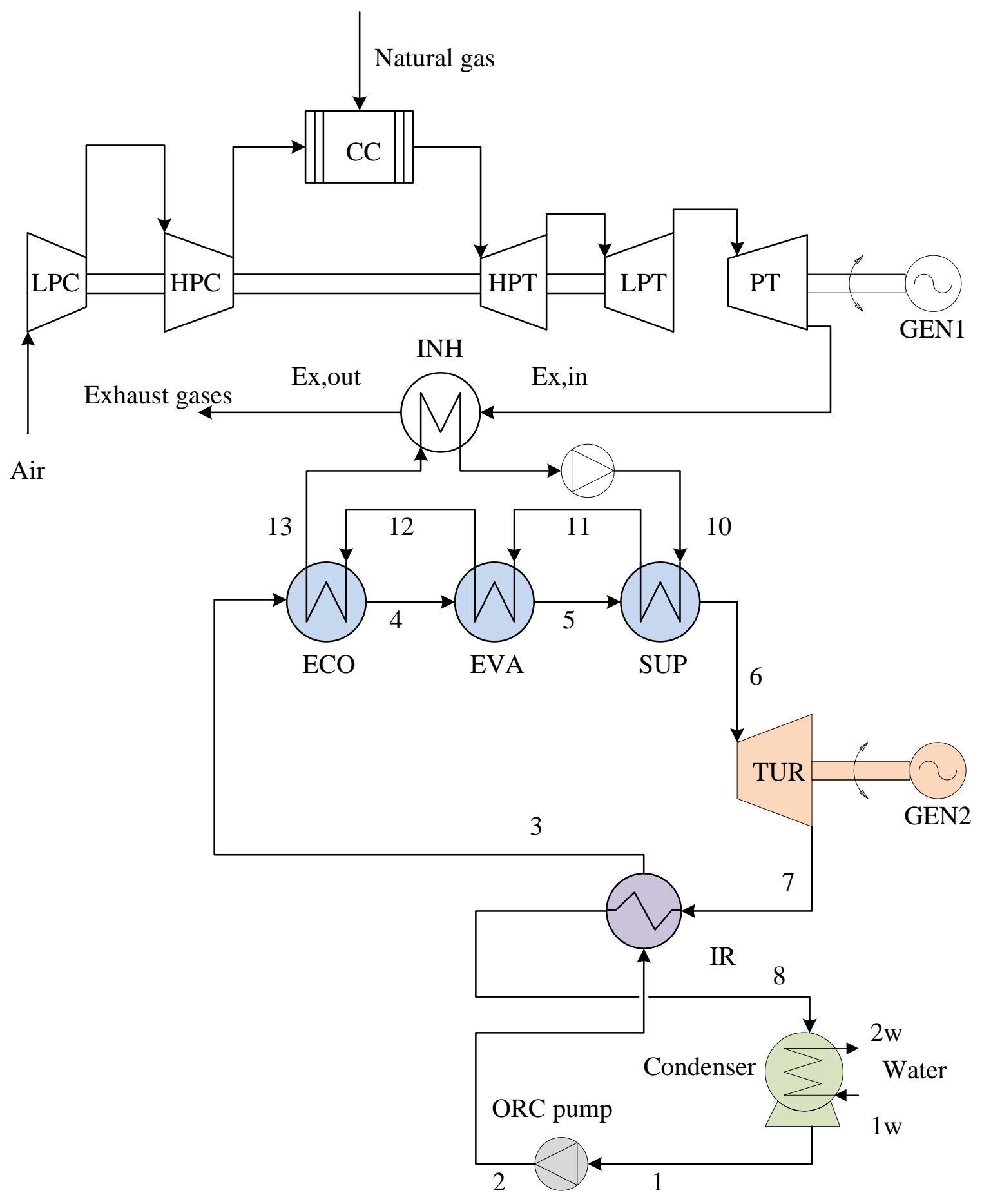

Figure 5. Combined cycle layout including the SGT-500 Siemens twin-spool gas turbine, the intermediate loop and the organic Rankine cycle. 
We apply the multi-objective optimization described in section 2.4 to design the ORC for recovering the waste heat from the SGT-500 gas turbine. Figure 5 shows the plant layout including the SGT-500 twin-spool gas turbine, the intermediate loop and the ORC. The design point parameters of the ORC are listed in Table 4 and are maintained constant. The terminal temperature of the off-gases exiting the waste heat recovery unit is fixed to $145^{\circ} \mathrm{C}$ [29]. A prudential value of $335^{\circ} \mathrm{C}$ [29] is assumed for the maximum temperature. We evaluate the cold temperature $\left(130^{\circ} \mathrm{C}\right)$ and the mass flow $(49.5 \mathrm{~kg} / \mathrm{s})$ of Dowtherm Q in the intermediate loop by applying an energy balance in the internal heat exchanger.

Table 4. Organic Rankine cycle parameters assumed in the multi-objective optimization.

\begin{tabular}{ll}
\hline Parameter & Value \\
\hline & \\
\hline Exhaust gas inlet temperature $t_{e x, i n}$ & $376^{\circ} \mathrm{C}$ \\
Exhaust gas outlet temperature $t_{e x, o u t}$ & $145^{\circ} \mathrm{C}[29]$ \\
Exhaust gas mass flow $\dot{m}_{e x}$ & $93.5 \mathrm{~kg} / \mathrm{s}$ \\
Dowtherm Q inlet temperature $t_{10}$ & $335^{\circ} \mathrm{C}[29]$ \\
Dowtherm Q outlet temperature $t_{13}$ & $130{ }^{\circ} \mathrm{C}$ \\
Dowtherm Q mass flow $\dot{m}_{d o w}$ & $49.5 \mathrm{~kg} / \mathrm{s}$ \\
Pump efficiency $\eta_{m}$ & $80 \%$ \\
Turbine polytropic efficiency & $80 \%$ \\
Generator efficiency $\eta_{e l}$ & $98 \%$ \\
Cooling water $t_{1 w}$ & $5{ }^{\circ} \mathrm{C}$ \\
\hline
\end{tabular}


Next, we must decide the necessary fluid allocation in order to dimension the shell and tube heat exchangers. Where a phase change occurs (evaporator and condenser) the ORC working fluid is placed on the shell side, since it is the most common configuration [21]. For the economizer and superheater, the fluid with the greatest tendency to foul (which is Dowtherm Q) is allocated on the tube side; while for the internal recuperator, the fluid with the highest temperature (working fluid exiting the ORC turbine) is placed on the tube side to reduce heat loss and meet safety conditions [21].

We expect two major sources of income with the installation of the waste heat recovery unit. The first is associated with the fuel savings and the second with the $\mathrm{CO}_{2}$ taxes. In fact, the power produced by the ORC enables a reduction of the load of the other gas turbines operating on the platform. Consequently, the saved natural gas can be exported and sold to the market. The income related to the saved natural gas $R_{N G}$ is estimated as follows:

$R_{N G}=3.6 \frac{\dot{P}_{n e t}}{\dot{P}_{G T}} p_{N G} h u \dot{V}_{N G}$

where $\dot{P}_{G T}$ is the gas turbine net power output, $h u$ is the utilization factor, $p_{N G}$ is the price of natural gas and $\dot{V}_{N G}$ is the volumetric flow of natural gas. The volumetric flow $\dot{V}_{N G}$ of natural gas is calculated as follows:

$\dot{V}_{N G}=v_{N G} \frac{\dot{P}_{\text {net }} H R}{3600 L H V}$

where $v_{N G}$ is the specific volume calculated at $15{ }^{\circ} \mathrm{C}$ and $1.013 \mathrm{bar}, H R$ is the heat rate of the gas turbine and $L H V$ is the low heat value of natural gas. The second major income is due to the $\mathrm{CO}_{2}$ tax. Since 1991 Norway levies carbon tax on petroleum, mineral fuel and natural gas with the rates based on the fuel's carbon content 
[39]. Thus, the new method alleviates the carbon tax cost associated with the combustion of natural gas. The income $R_{\mathrm{CO} 2}$ related to the $\mathrm{CO}_{2}$ savings is computed as follows:

$$
R_{\mathrm{CO} 2}=3.6 \frac{\dot{P}_{n e t}}{\dot{P}_{G T}} p_{C O 2} \text { hu } \dot{m}_{\mathrm{CO} 2}
$$

where $p_{\mathrm{CO} 2}$ is the carbon tax and $\dot{m}_{\mathrm{CO} 2}$ is the mass flow of the avoided carbon dioxide. The net present value of the SGT-500 and ORC combined cycle can be rewritten as

$$
N P V=\sum_{i=1}^{n} \frac{\mathrm{Ma}\left(R_{N G}+R_{C O 2}\right)}{(1+q)^{i}}-I_{T O T}
$$

where $M a$ is a non-dimensional factor that accounts for the operating and maintenance costs. The numerical values assumed in Eqs. (34)-(37) are reported in Table 5.

Table 5. Parameters assumed for the economic analysis.

\begin{tabular}{ll}
\hline Parameter & Value \\
\hline Natural gas price $p_{N G}$ & \\
Utilization factor $h u$ & $681.65 \mathrm{NOK} / \mathrm{tonm}^{3}{ }_{\mathrm{st}}[38]$ \\
Low heating value (natural gas) & $48530 \mathrm{~kJ} / \mathrm{kg}$ \\
Specific volume (natural gas) & $1.3139 \mathrm{~m}^{3} / \mathrm{kg}$ \\
Carbon tax & $410 \mathrm{NOK} / \mathrm{t} \mathrm{of} \mathrm{CO}$ [40] \\
Carbon dioxide emission rate & $2.75 \mathrm{~kg}\left(\mathrm{CO}_{2}\right) / \mathrm{kg}(\mathrm{NG})[41]$ \\
Maintenance & $0.9[26]$ \\
\hline
\end{tabular}




\begin{tabular}{ll}
\hline Equipment lifespan $n$ & $20 \mathrm{y}$ \\
Interest factor $q$ & $10 \%$ \\
Conversion factor & $0.18 \mathrm{NOK} / \$$ \\
\hline
\end{tabular}

\section{Results}

Table 6 lists the variables, and the lower and upper bounds set in the multi-objective optimization. The velocities of Dowtherm Q in the economizer, evaporator and superheater, and the velocity of the water in the condenser are not included in Table 6 . These are all set to $1 \mathrm{~m} / \mathrm{s}$. We assume that the pump work in the intermediate loop is negligible and that the inlet pressure of the water is sufficient to overcome the pressure drops associated with the flow through the condenser.

Table 6. Lower and upper bounds specified for the variables included in the multi-objective optimization (bounds for all velocities are taken from Richardson and Peacock [21]).

\begin{tabular}{lll}
\hline Parameter & Lower bound & Upper bound \\
\hline & $25^{\circ} \mathrm{C}$ & $35^{\circ} \mathrm{C}$ \\
Outlet condenser temperature $T_{1}$ & $10^{\circ} \mathrm{C}$ & $25^{\circ} \mathrm{C}$ \\
Condenser pinch point & $15^{\circ} \mathrm{C}$ & $40^{\circ} \mathrm{C}$ \\
Internal recuperator pinch point $T_{2}-T_{8}$ & $10^{\circ} \mathrm{C}$ & $30{ }^{\circ} \mathrm{C}$ \\
Evaporator or economizer pinch point & $10 \mathrm{bar}$ & $40 \mathrm{bar}$ \\
Turbine inlet pressure $p_{6}$ & $50{ }^{\circ} \mathrm{C}$ & $130{ }^{\circ} \mathrm{C}$ \\
Superheating temperature difference $T_{10}-T_{6}$ & $0.3 \mathrm{~m} / \mathrm{s}$ & $1 \mathrm{~m} / \mathrm{s}$ \\
Economizer velocity on the shell side & $5 \mathrm{~m} / \mathrm{s}$ & $10 \mathrm{~m} / \mathrm{s}$ \\
Evaporator velocity on the shell side &
\end{tabular}




\begin{tabular}{lll}
\hline Superheater velocity on the shell side & $5 \mathrm{~m} / \mathrm{s}$ & $10 \mathrm{~m} / \mathrm{s}$ \\
Internal recuperator velocity on the shell side & $0.3 \mathrm{~m} / \mathrm{s}$ & $1 \mathrm{~m} / \mathrm{s}$ \\
Internal recuperator velocity in the tubes & $10 \mathrm{~m} / \mathrm{s}$ & $30 \mathrm{~m} / \mathrm{s}$ \\
Condenser velocity on the shell side & $10 \mathrm{~m} / \mathrm{s}$ & $30 \mathrm{~m} / \mathrm{s}$ \\
\hline
\end{tabular}

We set a maximum GWP of 50 and a maximum physical, fire and health hazards level of 3 in the pre-screening process of the available working fluids. The pre-screening process decreases the number of available working fluids from 109 down to 20. The GWP boundary excludes all the refrigerants (namely R113, R114, RC318 and R134A) except for R1234YF and R1234ZE. Gaseous fluids, such as air, were eliminated because their critical temperatures are below $25^{\circ} \mathrm{C}$ (Table 6). The limit on the fire hazard eliminates fluids that may ignite spontaneously with air (e.g. ethane, butane, pentane, propane and methane). Among the available fluids, seven (hexane, i-hexane, heptane, decane, nonane, octane, dodecane) belong to the alkane class and five (methylcyclohexane, propylcyclohexane, cyclohexane, cyclopentane and cyclopropane) to the cycloalkane group. Other possible fluids are acetone, ammonia, benzene, ethanol, methanol, carbon dioxide, toluene and trifluoroiodomethane. The results suggest that variations of the GWP limits and of the hazard levels do not change the results considerably. The multi-objective optimization provides a three-dimensional Pareto front composed of 350 points. The GA selects two fluids, cyclopentane and acetone, as optimal. In general cyclopentane shows the highest efficiency, but at the cost of greater total volumes and investment. However, regarding the net present value, cyclopentane is the best choice.

Figure 6 depicts the total volume of the ORC plant versus the thermal efficiency. Acetone exhibits a Pareto front ranging from a thermal efficiency of 23.7 to $27.0 \%$ and from a volume of 14.5 to $57.5 \mathrm{~m}^{3}$. For cyclopentane, the thermal efficiency varies from 27.0 to $28.1 \%$ and the volume ranges from 55.0 to $98.4 \mathrm{~m}^{3}$. 


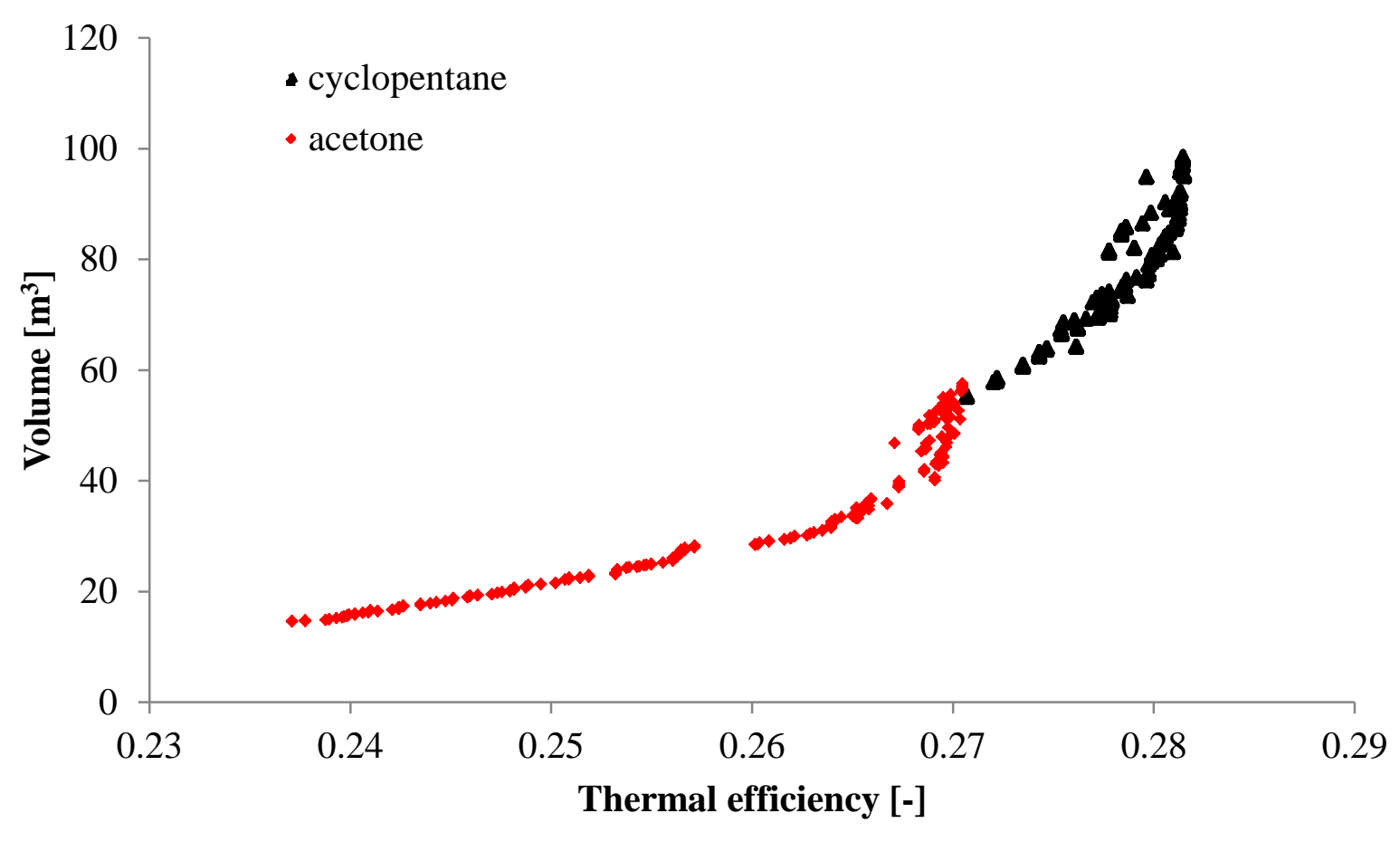

Figure 6. Pareto fronts (acetone and cyclopentane) obtained through the multi-objective optimization representing the total volume of the ORC versus thermal efficiency.

The net present value is given as a function of the total volume in Fig. 7. The $N P V$ increases from 17.7 up to 19.8 M\$ for acetone and from 19.7 up to 20.1 M\$ for cyclopentane. It can be noticed that the trend of the two Pareto fronts initially increases and subsequently flattens out. Since the net present value is a function of the total investment cost and the yearly incomes (dependent on the thermal efficiency of the ORC), an optimum is reached at a volume of $49.8 \mathrm{~m}^{3}$ for acetone and $86.2 \mathrm{~m}^{3}$ for cyclopentane. After this maximum, increasing the performance of the ORC by increasing the volume diminishes the economic revenue since the total investment cost becomes too high. 


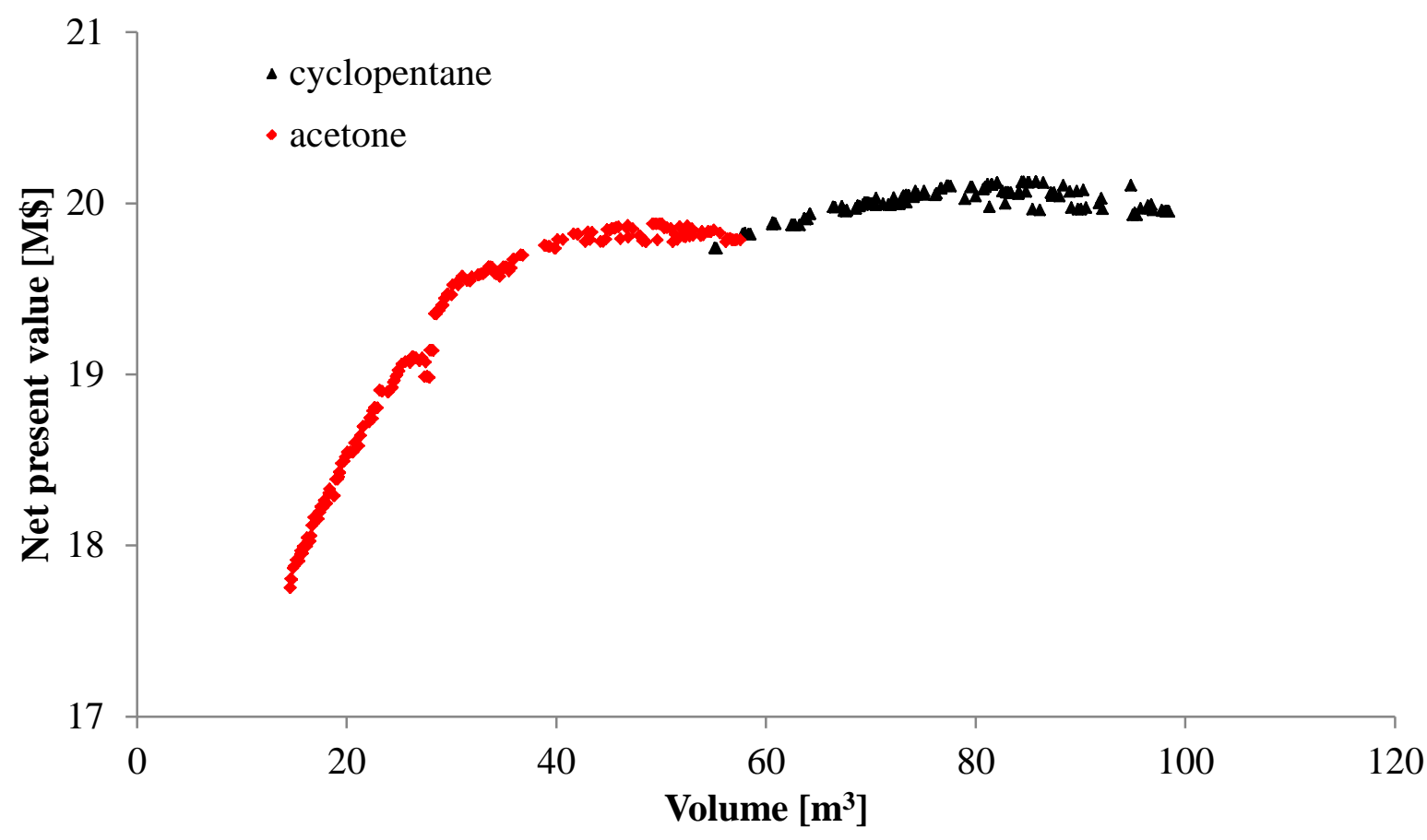

Figure 7. Pareto fronts (acetone and cyclopentane) obtained through the multi-objective optimization representing the net present value versus the total volume of the ORC.

To illustrate how other working fluids perform, we run the multi-objective optimization excluding acetone and cyclopentane from the candidates. The results are shown in Figs. (8) and (9), where the Pareto fronts of the three optimal fluids (cyclohexane, hexane and i-hexane) are reported. The population size in the GA is limited to 500. 


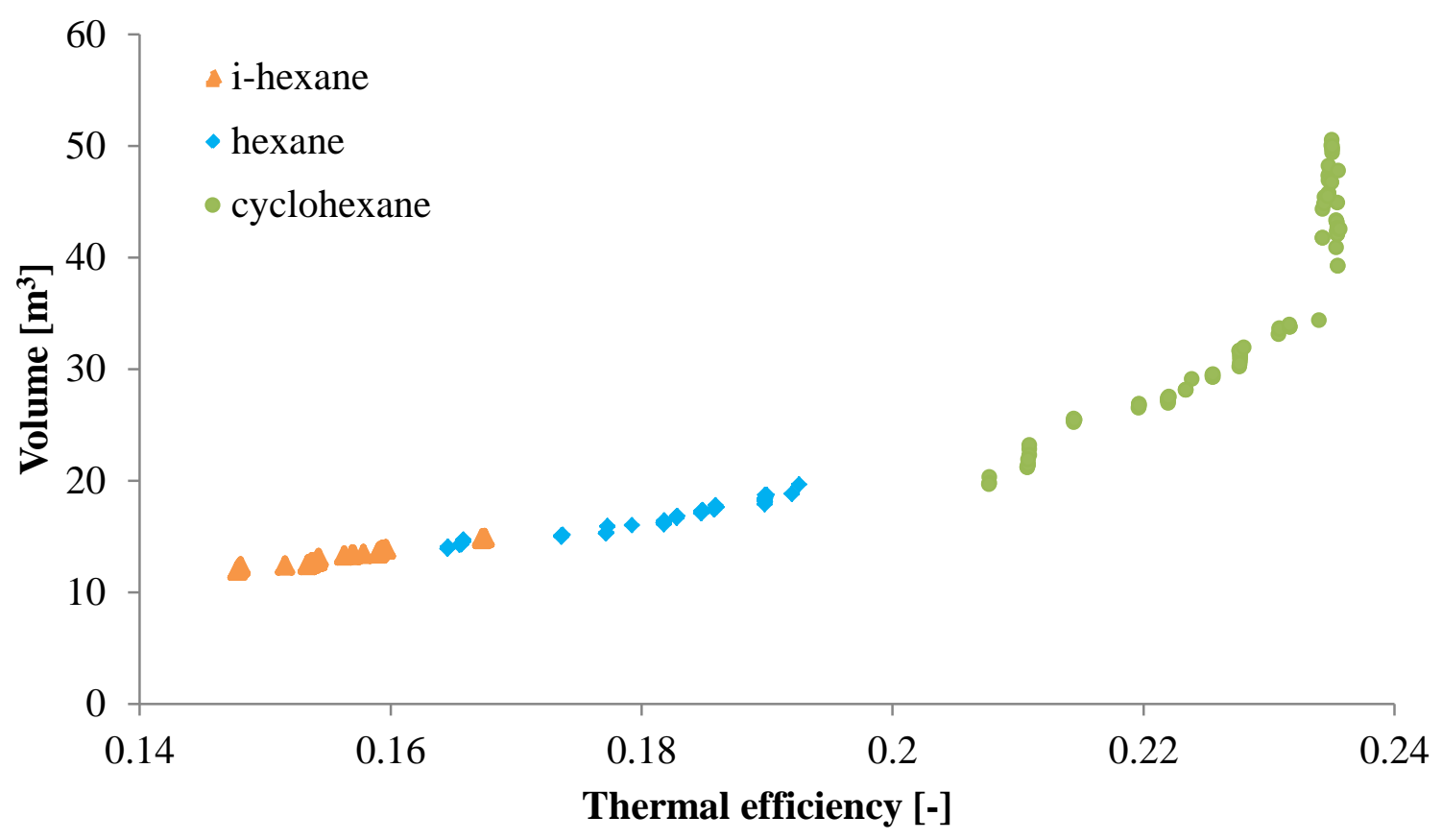

Figure 8. Pareto fronts (cyclohexane, hexane and i-hexane) obtained through the multi-objective optimization representing the total volume of the ORC versus thermal efficiency. Cyclopentane and acetone are excluded.

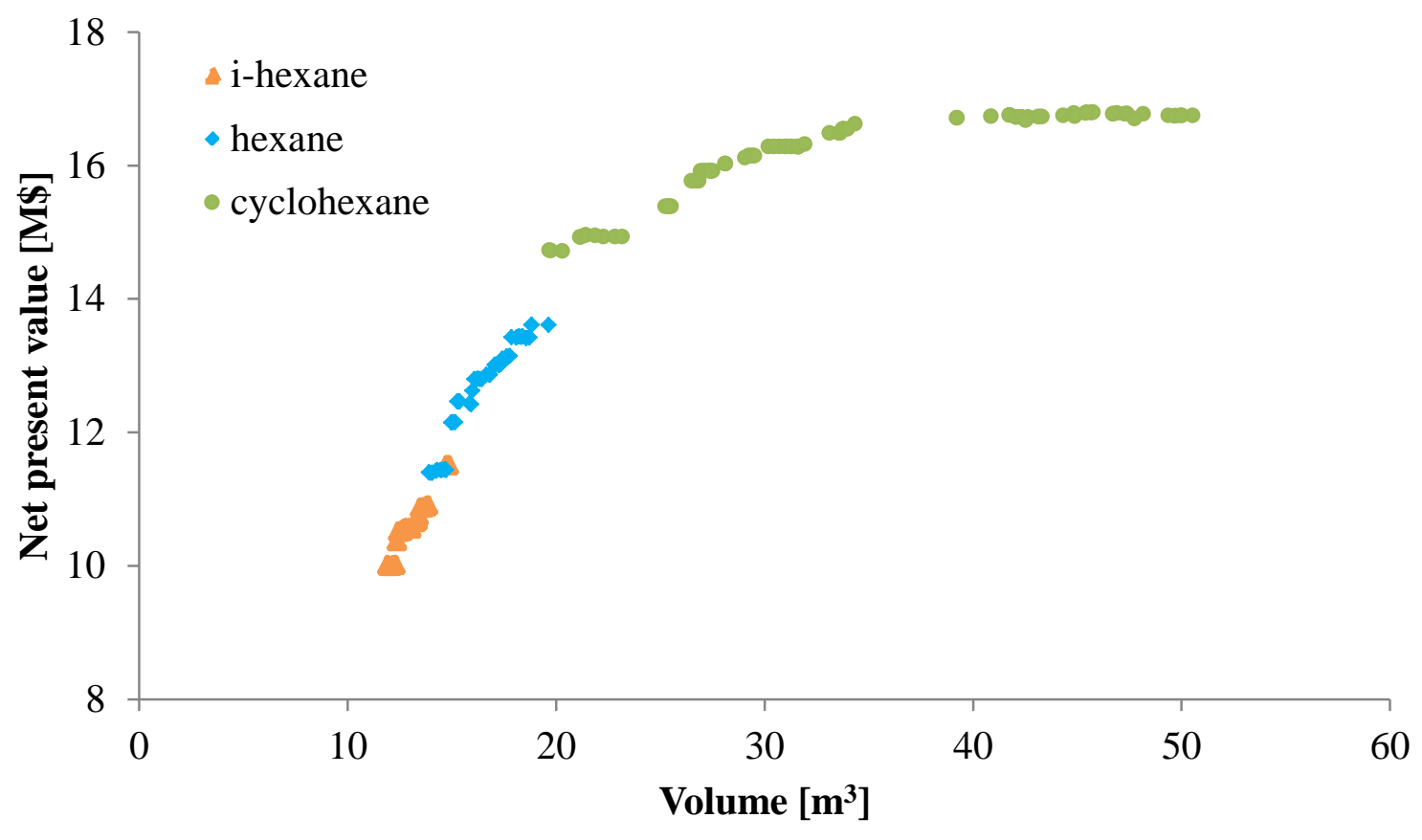


Figure 9. Pareto fronts (cyclohexane, hexane and i-hexane) obtained through the multi-objective optimization representing the net present value versus the total volume of the ORC. Cyclopentane and acetone are excluded.

The trend of the thermal efficiency versus total volume and of the total volume versus net present value for both acetone and cyclopentane can be fitted by interpolating the results shown in Figs. (6) and (7) using the commercial software TableCurve 2D v5.01 [42].

$\frac{1}{V_{t o t}}=a+b \eta_{t h}^{3}$

$N P V^{2}=c+d V_{t o t}+e V_{t o t}^{2}$

Table 7 reports the coefficients $a, b, c, d, e$ and the coefficient of determination for acetone and cyclopentane. Table 7. Coefficients $a, b, c, d$, e and coefficient of determination for acetone and cyclopentane obtained by interpolating in the Pareto fronts in Figs. (6) and (7).

\begin{tabular}{lcc}
\hline Coefficient & Acetone & \multicolumn{1}{l}{ Cyclopentane } \\
\hline & & \\
a & 0.1629 & 0.0802 \\
b & -7.3035 & -3.1202 \\
Coefficient of determination for Eq. (38) & 0.9580 & 0.8858 \\
c & 230.9653 & 277.1201 \\
d & 7.0789 & 3.0718 \\
e & -0.0759 & -0.0187 \\
Coefficient of determination for Eq. (39) & 0.9905 & 0.8197 \\
\hline
\end{tabular}


Regarding the optimization variables, the pinch point is located in the evaporator rather than in the economizer and it ranges between 13.9 and $19.6^{\circ} \mathrm{C}$. The minimum temperature difference in the condenser is constant along the Pareto front $\left(20.0^{\circ} \mathrm{C}\right.$ in average). The optimal turbine inlet pressure varies between 37.2 and 39.7 bar, and it almost reaches the upper bound of 40 bar (see Table 6). The profile of the outlet temperature of the condenser throughout the Pareto front ranges from 25.9 up to $29.5^{\circ} \mathrm{C}$ for acetone and from 25.9 up to $27.1^{\circ} \mathrm{C}$ for cyclopentane.

Figures 6 and 7 enable the selection of the design point of the ORC employed as the waste heat recovery unit for the SGT-500 gas turbine. If an upper limit for the total volume is specified and the NPV increases at greater volumes, the optimal solution corresponds to that of the maximal acceptable total volume. On the contrary, if the NPV decreases or if the specified volume is greater than the maximum volume in the Pareto front, the optimum is located where the NPV is maximized. For example, if the available volume is lower than $30 \mathrm{~m}^{3}$, the optimal solution falls in the acetone Pareto front at a total volume of $29.9 \mathrm{~m}^{3}$; the thermal efficiency and net present value are $26.1 \%$ and 19.4 M\$ (see Figs. (6) and (7)). If the available volume is greater than $100 \mathrm{~m}^{3}$, cyclopentane is the most suitable working fluid and an optimum is set where the NPV reaches the maximum (20.1 M\$). This corresponds to a total volume of $86.2 \mathrm{~m}^{3}$ and a thermal efficiency of $27.8 \%$. The discounted payback period for both cases is estimated to be around 5 years. Table 8 lists the geometry, the volume and the investment cost of the heat exchangers and axial turbine for the two alternatives. It can be noted that the largest components are the internal recuperator, the economizer and the condenser. In the internal recuperator, the heat is exchanged between liquid and vapor, thus the heat transfer coefficient of the vapor side is relatively low. The economizer and the condenser are associated with a high overall heat transfer coefficient. However, a large volume is required since a large heat rate is exchanged.

Table 8. Geometry, investment cost and volume for the proposed optimal solution selected from the Pareto front of acetone and cyclopentane. 


\begin{tabular}{|c|c|c|}
\hline & Case a) & Case b) \\
\hline ORC thermal efficiency & $26.1 \%$ & $27.8 \%$ \\
\hline ORC net power output & $6.04 \mathrm{MW}$ & $6.43 \mathrm{MW}$ \\
\hline Total volume & $29.9 \mathrm{~m}^{3}$ & $86.2 \mathrm{~m}^{3}$ \\
\hline Net present value & 19.4 M\$ & $20.1 \mathrm{M} \$$ \\
\hline Discounted payback time & 4.9 year & 5.2 year \\
\hline \multicolumn{3}{|l|}{ Economizer } \\
\hline Tube length & $5.44 \mathrm{~m}$ & $17.51 \mathrm{~m}$ \\
\hline Tube diameter & $17.3 \mathrm{~mm}$ & $37.3 \mathrm{~mm}$ \\
\hline Baffle spacing & 0.29 & 0.28 \\
\hline Pitch ratio & 1.36 & 1.13 \\
\hline Volume & $5.77 \mathrm{~m}^{3}$ & $32.8 \mathrm{~m}^{3}$ \\
\hline Purchased-equipment cost & $0.1195 \mathrm{M} \$$ & $0.2137 \mathrm{M} \$$ \\
\hline \multicolumn{3}{|l|}{ Evaporator } \\
\hline Tube length & $7.16 \mathrm{~m}$ & $6.66 \mathrm{~m}$ \\
\hline Tube diameter & $25.8 \mathrm{~mm}$ & $21.7 \mathrm{~mm}$ \\
\hline Baffle spacing & 0.27 & 0.28 \\
\hline Pitch ratio & 1.41 & 1.40 \\
\hline Volume & $1.84 \mathrm{~m}^{3}$ & $1.8 \mathrm{~m}^{3}$ \\
\hline Purchased-equipment cost & $0.0335 \mathrm{M} \$$ & $0.0378 \mathrm{M} \$$ \\
\hline \multicolumn{3}{|l|}{ Superheater } \\
\hline Tube length & $4.19 \mathrm{~m}$ & $8.6 \mathrm{~m}$ \\
\hline Tube diameter & $16.0 \mathrm{~mm}$ & $16.3 \mathrm{~mm}$ \\
\hline
\end{tabular}




\begin{tabular}{|c|c|c|}
\hline Baffle spacing & 0.32 & 0.36 \\
\hline Pitch ratio & 1.55 & 1.9 \\
\hline Volume & $1.44 \mathrm{~m}^{3}$ & $2.8 \mathrm{~m}^{3}$ \\
\hline Purchased-equipment cost & $0.0415 \mathrm{M} \$$ & $0.0679 \mathrm{M} \$$ \\
\hline \multicolumn{3}{|l|}{ Internal recuperator } \\
\hline Tube length & $1.33 \mathrm{~m}$ & $2.24 \mathrm{~m}$ \\
\hline Tube diameter & $41.1 \mathrm{~mm}$ & $45.9 \mathrm{~mm}$ \\
\hline Baffle spacing & 0.29 & 0.29 \\
\hline Pitch ratio & 1.02 & 1.01 \\
\hline Volume & $12.0 \mathrm{~m}^{3}$ & $37.6 \mathrm{~m}^{3}$ \\
\hline Purchased-equipment cost & $0.1157 \mathrm{M} \$$ & $0.2316 \mathrm{M} \$$ \\
\hline \multicolumn{3}{|l|}{ Condenser } \\
\hline Tube length & $1.19 \mathrm{~m}$ & $1.59 \mathrm{~m}$ \\
\hline Tube diameter & $16.0 \mathrm{~mm}$ & $16.9 \mathrm{~mm}$ \\
\hline Baffle spacing & 0.31 & 0.31 \\
\hline Pitch ratio & 1.55 & 1.52 \\
\hline Volume & $8.2 \mathrm{~m}^{3}$ & $10.4 \mathrm{~m}^{3}$ \\
\hline Purchased-equipment cost & $0.2003 \mathrm{M} \$$ & $0.2609 \mathrm{M} \$$ \\
\hline \multicolumn{3}{|l|}{ Axial turbine } \\
\hline Axial speed & $66.3 \mathrm{~m} / \mathrm{s}$ & $58.3 \mathrm{~m} / \mathrm{s}$ \\
\hline Volume & $0.5 \mathrm{~m}^{3}$ & $0.5 \mathrm{~m}^{3}$ \\
\hline Purchased-equipment cost & $2.7656 \mathrm{M} \$$ & $2.9181 \mathrm{M} \$$ \\
\hline
\end{tabular}

\section{Discussion}


We compare the shell and tube heat exchanger model, outlined in subsection 2.1, using an example outlined in Richardson and Peacock [21], comprising the design of a heat exchanger to sub-cool condensate from a methanol condenser with the use of liquid water as coolant. The results indicate differences less than $1 \%$ in overall heat transfer coefficients and pressure drops between the models derived here and the results provided in Richardson and Peacock [21]. These small differences are expected to be caused by differences in the calculations of thermodynamic properties of fluids, suggesting that the shell and tube heat exchanger model derived here gives reasonable results.

The total investment cost for case a) is $13.1 \mathrm{M} \$$ and $15.0 \mathrm{M} \$$ for case $\mathrm{b})$. The axial turbine is the major contributor to the total investment cost of the ORC, namely, $78.6 \%$ and $72.5 \%$ for case a) and b). In Gonçalves et al. [43], the price of the expander and generator represents $48.4 \%$ of the total cost of a $385 \mathrm{~kW}$ ORC fuelled by sawmill wastes. However, the presence of a boiler increases the total expense by around 24.2\%. Assuming the component prices reported in Gonçalves et al. [43] and a conversion factor of $1.31 \$ / €$, the total investment cost calculated with Eq. (33) is $18.4 \%$ lower for case a) and $10.1 \%$ lower for case b). The total investment cost calculated with Eq. (33) is also compared with the results of an equation derived in Ghirardo et al. [44] utilizing the cost of the Turboden T1100-CHP ORC and a scale factor coefficient equal to 0.867 . The investment costs computed with Eq. (33) are 22.8\% and 28.8\% greater than the values calculated with Ghirardo’s approach. Findings suggest that the pay-back time is within the same range (4-6 years) as the one reported by Wang et al. [18] for heat source temperatures of $120^{\circ} \mathrm{C}$ and $140{ }^{\circ} \mathrm{C}$. The results of these comparisons suggest that the economic analysis in this paper is in accordance with the results available in the literature.

In accordance with the results presented in Sun and Li [8] and Roy et al. [9], higher expander inlet pressures provide a higher net power generation and a higher compactness of the economizer, evaporator and superheater. Similarly to the works carried out by Roy et al. [9], Baik et al. [12] and Dai et al. [14], an optimal value for the turbine inlet temperature can be found. In this paper average turbine inlet temperatures of $320^{\circ} \mathrm{C}$ (cyclopentane) 
and of $300{ }^{\circ} \mathrm{C}$ (acetone) are found to be the optimal compromise between system performance, compactness and economic revenue. As is also suggested in Baik et al. [12], increasing the size of the evaporator and condenser enhances the thermal efficiency of the ORC (see Figs. (6) and (8)). However, this results in a higher investment cost of the heat transfer equipment. Hence, an optimal volume is found where the net present value reaches the maximum (see Figs. (7) and (9)).

As reported in section 3, the multi-objective process indicates that acetone and cyclopentane are the optimal working fluids in terms of efficiency, compactness and economy. The optimal working fluids differ from the ones suggested in previous works refs. [8-18] since in this paper the heat source is at around $370{ }^{\circ} \mathrm{C}$ while in refs. [8-18] the heat source is at lower temperature level $\left(100-200^{\circ} \mathrm{C}\right)$. However, acetone and cyclopentane are suggested to be suitable working fluids for ORC applications also in other works. In He et al. [45], cyclopentane provides the highest thermal efficiency (20.8\%) in an ORC used for waste heat recovery of an internal combustion engine. Lai et al. [46] rank cyclopentane as the third best working fluid: ORC net power output is 1 MW and the heat carrier inlet and outlet temperatures are $280^{\circ} \mathrm{C}$ and $350^{\circ} \mathrm{C}$. Ginosar et al. [47] assess the thermal stability of cyclopentane. The authors measure a decomposition rate up to $1500 \mathrm{ppm}$ at $350{ }^{\circ} \mathrm{C}$ [47]. The maximum temperature in the ORC should then be lower than $300^{\circ} \mathrm{C}$ where the decomposition rate is in the order of $270 \mathrm{ppm}$ [47]. In the present paper, the highest turbine inlet temperature is $276.9^{\circ} \mathrm{C}$. Wang et al. [48] show that acetone exhibits the lowest exergy destruction in the overall ORC for low-temperature waste heat recovery. However, the authors discard the fluid, since the condensing pressure is less than the atmospheric pressure leading to the infiltration of ambient air into the loop. As reported by Dai et al. [14], low specific volumes are crucial to decrease the dimensions of the expander. As surveyed by Nouman [49], acetone presents the lowest volumetric flow rate and expansion ratio in ORC applications. Therefore, the fluid is proposed for the design of compact ORCs, since the size and material cost of the system are reduced. 
The present methodology can be implemented to design ORC units converting heat at different temperature levels into electric or mechanical power. At each temperature level, the three-dimensional Pareto front for each optimal working fluid is identified. In the multi-objective optimization method proposed in Salcedo et al. [17], the objective functions are the environmental impact and the specific cost of a solar steam Rankine cycle. Wang et al. [18] employs the heat exchanger area per unit power output and heat recovery efficiency as targets. In this paper the desired compactness and economic revenue can be selected from the optimal front (see Figs. (6) and (7)). As an improvement of the work presented by Wang et al. [18], in this work the optimal pinch points and the fluid velocities in the shell and on the tubes side of economizer, evaporator, superheater, and internal recuperator can be identified. In contrast with Wang et al. [18] where simple heat transfer and pressure drop correlations for horizontal tubes are employed, this paper introduces specific equations (see Eqs. (5)-(11)) for the shell and tube heat exchanger in the multi-objective optimization. Thus, the geometry of the heat transfer equipment can be assessed and utilized to select available components on the market.

However, since the heat transfer equipment considered in this analysis is the shell and tube heat exchanger, the field of application is directed towards MW-size systems with high temperature heat sources $\left(350{ }^{\circ} \mathrm{C}-250{ }^{\circ} \mathrm{C}\right)$. In fact, shell and tube heat exchangers are normally employed for high temperature and pressure processes. At a maximum operating temperature and pressure in the ORC lower than $250{ }^{\circ} \mathrm{C}$ and 30 bar and at mass flow rates lower than $2500 \mathrm{~m}^{3} / \mathrm{h}$ [21], the plate heat exchanger are the preferable heat transfer equipment due to its flexibility and compactness. The algorithm provides also the geometry of the economizer, evaporator, superheater, internal recuperator and condenser. Hence, the standard dimensions of the tubes (outer diameter and length), the shell diameter, the baffle spacing and the pitch ratio can be selected directly from the outcomes of the shell and tube design process. However, for a more accurate estimation of the overall heat transfer coefficient and of the pressure drop, specific correlations for the selected working fluid should replace the more generic approach presented in section 2.1. 


\section{Conclusions}

We propose a multi-objective optimization that considers the thermal efficiency, compactness and net present value, by employing the genetic algorithm to design organic Rankine cycles. The shell and tube heat exchangers are the heat transfer equipment. The space requirement of the ORC is assessed by calculating the geometry (tube diameter and length, pitch and baffle spacing) of the shell and tube heat exchanger following a well-established design procedure. We employ different heat transfer correlations depending on the fluid phase, and we also quantify pressure drops within the cycle. The variables considered in the optimization routine are the turbine inlet pressure, pinch points of the evaporator, superheater, internal recuperator and condenser, the velocity on the shell side of the heat exchangers, and the temperature at the outlet of the condenser.

We apply the methodology to recover the waste heat from the SGT-500 gas turbine utilized to support the power demand in the Draugen off-shore platform. The results suggest that the two most suitable working fluids are acetone and cyclopentane. For acetone, the thermal efficiency ranges from 23.7 to $27.0 \%$, in volume from 14.5 to $57.5 \mathrm{~m}^{3}$, and in net present value from 17.7 to $19.8 \mathrm{M}$ \$. Cyclopentane performs better both in terms of thermal efficiency (27.0 to $28.1 \%$ ) and of net present value (19.7 to 20.1 M\$). However, the usable volume becomes larger (55.0 to $98.4 \mathrm{~m}^{3}$ ). Based on the volume versus thermal efficiency and NPV versus volume curves, we propose two possible solutions and list the geometry of the economizer, evaporator, superheater, internal recuperator and condenser.

\section{Acknowledgements}

The funding from the Norwegian Research Council through Petromaks with project number 203404/E30 is acknowledged. We also acknowledge the kind support from Siemens Industrial Turbomachinery AB, Finspång, Sweden for providing necessary technical documentation. 


\section{Nomenclature}

\section{Abbreviations}

CC combustion chamber

$D C$

$D P B \quad$ discounted payback period [year]

ECO economizer

EVA evaporator

GA genetic algorithm

GEN electric generator

GT gas turbine

GWP

HPC

HPT

INH

IR

$L H V$

$L P C$

LPT low-pressure turbine

NG natural gas

NPV net present value

ORC organic Rankine cycle

PEC purchased-equipment cost

PT $\quad$ power turbine

SUP superheater
TUR turbine

\section{Notations}

$$
A \quad \text { area }\left[\mathrm{m}^{2}\right]
$$

$a, b, c, d, e \quad$ coefficients in Eqs. (38) and (39)

$b_{c} \quad$ baffle cut

c $\quad$ speed $[\mathrm{m} / \mathrm{s}]$

$c_{p} \quad$ specific heat capacity $\left[\mathrm{kJ} /\left(\mathrm{kg}^{\circ} \mathrm{C}\right)\right]$

$d \quad$ diameter [m]

$f \quad$ function

$F_{t} \quad$ temperature correction factor

$F_{t s} \quad$ heat exchanger correction factor

$F_{t v} \quad$ turbine correction factor

$g \quad$ acceleration of gravity $\left[\mathrm{m} / \mathrm{s}^{2}\right]$

$h \quad$ heat transfer coefficient $\left[\mathrm{W} /\left(\mathrm{m}^{2}{ }^{\circ} \mathrm{C}\right)\right]$

or enthalpy $[\mathrm{kJ} / \mathrm{kg}]$

hu utilization factor [h/y]

HR heat rate $[\mathrm{kJ} / \mathrm{kWh}]$

$I_{\text {TOT }} \quad$ total capital investment [\$]

$i \quad$ year

$j_{t h} \quad$ tube side heat transfer factor

$j_{t f} \quad$ tube side friction factor

$j_{\text {sh }} \quad$ shell side heat transfer factor

$j_{s f} \quad$ shell side friction factor 


\begin{tabular}{|c|c|c|c|}
\hline$l$ & length [m] & $u$ & fluid velocity $[\mathrm{m} / \mathrm{s}]$ \\
\hline$L H V$ & lower heating value $[\mathrm{kJ} / \mathrm{kg}]$ & $V$ & volume $\left[\mathrm{m}^{3}\right]$ \\
\hline$M$ & molecular mass [kg/kmol] & $v$ & specific volume $\left[\mathrm{m}^{3} / \mathrm{kg}\right]$ \\
\hline$M a$ & operating and maintenance factor & $\dot{V}$ & volume rate $\left[\mathrm{m}^{3} / \mathrm{s}\right]$ \\
\hline$m$ & exponent in Eq. (6) & $\dot{W}$ & mechanical power [kW] \\
\hline$\dot{m}$ & mass flow $[\mathrm{kg} / \mathrm{s}]$ & & \\
\hline$N_{t}$ & number of tubes & \multicolumn{2}{|c|}{ Greek symbols } \\
\hline$n$ & number of years & $\Delta$ & difference \\
\hline$N P V$ & net present value & $\rho$ & density $\left[\mathrm{kg} / \mathrm{m}^{3}\right]$ \\
\hline$N u$ & Nusselt number & $\lambda$ & thermal conductivity $\left[\mathrm{kW} /\left(\mathrm{m}^{\circ} \mathrm{C}\right)\right]$ \\
\hline$\dot{P}$ & electric power $[\mathrm{kW}]$ & $\mu$ & dynamic viscosity [N s/m²] \\
\hline$p$ & pressure $[\mathrm{Pa}]$ or price $[\mathrm{NOK} /$ tons $]$ & $\Gamma$ & tube loading $[\mathrm{kg} /(\mathrm{m} \mathrm{s})]$ \\
\hline$p_{t}$ & tube pitch [m] & $\eta$ & efficiency \\
\hline$P E C$ & purchased-equipment cost & & \\
\hline $\operatorname{Pr}$ & Prandtl number & \multicolumn{2}{|c|}{ Subscripts } \\
\hline$q$ & interest factor & $b$ & baffle \\
\hline$\dot{Q}$ & heat rate $[\mathrm{kW}]$ & $\mathrm{CO}_{2}$ & carbon dioxide \\
\hline$R$ & yearly income $[\$ / y]$ & cond & condenser \\
\hline$R_{p}$ & surface roughness $[\mu \mathrm{m}]$ & $e$ & equivalent \\
\hline$R e$ & Reynolds number & eco & economizer \\
\hline$T$ & temperature $[\mathrm{K}]$ & $e l$ & electric \\
\hline$t$ & temperature $\left[{ }^{\circ} \mathrm{C}\right]$ & eva & evaporator \\
\hline$U$ & overall heat transfer coefficient & $g$ & gas \\
\hline$[\mathrm{kW} /($ & & gen & generator \\
\hline
\end{tabular}




\begin{tabular}{|c|c|c|c|}
\hline$h t$ & heat exchanger & $r$ & reduced \\
\hline$i$ & inside & $s$ & shell \\
\hline$i d$ & inside dirt coefficient & sup & superheater \\
\hline in & inlet & $s w$ & shell wall \\
\hline$l$ & liquid & $t$ & tube \\
\hline $\operatorname{lm}$ & logarithmic mean & $t h$ & thermal \\
\hline$m$ & mechanical & tot & total \\
\hline$n b$ & nucleate boiling & ts & target shell \\
\hline net & net & $t t$ & target tube \\
\hline$o$ & outside & tur & turbine \\
\hline$o d$ & outside dirt coefficient & $t w$ & tube wall \\
\hline out & outlet & $w$ & wall or water \\
\hline$p$ & pump & $x$ & axial \\
\hline
\end{tabular}




\section{References}

[1] Commission of the European Communities. Europe's climate change opportunity. Communication from the Commission to the European Parliament, the Council, the European Economic and Social Committee and the Committee of the Regions, Brussels, Belgium; 2008.

[2] De Paepe M. Situation of the ORCNext project. In: Proceedings of the International Symposium on Advanced Waste Heat Valorization Technologies (September 13, Lecture n¹), September 13-14, Kortrijk, Belgium; 2012.

[3] Colonna P. Development from early days, current status and an outlook on relevant research topics and new applications. In: Proceedings of the International Symposium on Advanced Waste Heat Valorization Technologies (September 13, Lecture n²), September 13-14, Kortrijk, Belgium; 2012.

[4] Gewald D, Karellas S, Schuster A, Spliethoff H. Integrated system approach for increase of engine combined cycle efficiency. Energy Conversion and Management 2012; 60:36-44.

[5] Rokni M. Plant characteristics of an integrated solid oxide fuel cell cycle and a steam cycle. Energy 2010; 35:4691-4699.

[6] Domingues A, Santos H, Costa M. Analysis of vehicle exhaust waste heat recovery potential using a Rankine cycle. Energy 2013; 49:71-85. 
[7] Vélez F, Segovia J J, Martín C M, Antolín G, Chejne F, Quijano A. A technical, economical and market review of organic Rankine cycles for the conversion of low-grade heat for power generation. Renewable and Sustainable Energy Reviews 2012; 16:4175-4189.

[8] Sun J, Li W. Operation optimization of an organic rankine cycle (ORC) heat recovery power plant. Applied Thermal Engineering 2011; 31:2032-2041.

[9] Roy J P, Mishra M K, Misra A. Parametric optimization and performance analysis of a waste heat recovery system using Organic Rankine Cycle. Energy 2010; 35:5049-5062.

[10] Hettiarachchi H D M, Golubovic M, Worek W M, Ikegami Y. Optimum design criteria for an organic Rankine cycle using low-temperature geothermal sources. Energy 2007; 32:1698-1706.

[11] Quoilin S, Declaye S, Tchanche B F, Lemort V. Thermo-economic optimization of waste heat recovery Organic Rankine Cycles. Applied Thermal Engineering 2011; 31:2885-2893.

[12] Baik Y-J, Kim M, Chang K-C, Lee Y-S, Yoon H-K. A comparative study of power optimization in lowtemperature geothermal heat source driven R125 transcritical cycle and HFC organic Rankine cycles. Renewable Energy 2013; 54:78-84.

[13] Wang J, Yan Z, Wang M, Ma S, Dai Y. Thermodynamic analysis and optimization of an (organic Rankine cycle) ORC using low grade heat source. Energy 2013; 49:356-365.

[14] Dai Y, Wang J, Gao L. Parametric optimization and comparative study of organic Rankine cycle (ORC) for low grade waste heat recovery. Energy Conversion and Management 2009; 50:576-582. 
[15] Cayer E, Galanis N, Nesreddine H. Parametric study and optimization of a transcritical power cycle using a low temperature source. Applied Energy 2010; 87(4):1349-1357.

[16] Shengjun Z, Huaixin W, Tao G. Performance comparison and parametric optimization of subcritical Organic Rankine Cycle (ORC) and transcritical power cycle system for low-temperature geothermal power generation. Applied Energy 2011; 88:2740-2754.

[17] Salcedo R, Antipova E, Boer D, Jiménez L, Guillén-Gosálbez G. Multi-objective optimization of solar Rankine cycles coupled with reverse osmosis desalination considering economic and life cycle environmental concerns. Desalination 2012; 286:358-371.

[18] Wang Z Q, Zhou N J, Guo J, Wang X Y. Fluid selection and parametric optimization of organic Rankine cycle using low temperature waste heat. Energy 2012; 40:107-115.

[19] American coatings association. HMIS ${ }^{\circledR}$ IMPLEMENTATION MANUAL, 3rd ed. www.paint.org/programs/hmis.html [Accessed 07/02/2013].

[20] Fakheri A. A General Expression for the Determination of the Log Mean Temperature Correction Factor for Shell and Tube Heat Exchangers. Journal of Heat Transfer 2003; 125(3):527-530.

[21] Richardson J F, Peacock D G. Chemical and Biochemical Reactors and Process Control (Coulson and Richardson's Chemical Engineering; Volume 3). 3rd ed. Oxford, UK: Elsevier; 1994. ISBN 978-0-08-041003-6. 
[22] Hall S G. Capital cost targets for heat exchanger networks comprising mixed materials of construction, pressure ratings and exchanger types. Chemical Engineering 1990; 14(3):319-335.

[23] Kern D Q. Process Heat Transfer. Singapore: McGraw-Hill; 1950. ISBN 0-07-Y85353-3.

[24] Cooper M G. Heat flow rates in saturated nucleate pool boiling - A wide-ranging examination using reduced properties. Advances in Heat Transfer 1984; 16:157-239.

[25] Arsalis A, Spakovsky von R M, Calise F. Thermoeconomic Modeling and Parametric Study of Hybrid Solid Oxide Fuel Cell-Gas Turbine-Steam Turbine Power Plants Ranging From 1.5 MWe to 10 MWe. Journal of Fuel Cell Science and Technology 2009; 6:011015-1.

[26] Lian Z T, Chua K J, Chou S K. A thermoeconomic analysis of biomass energy for trigeneration. Applied Energy 2010; 87:84-95.

[27] Colonna P, Rebay S, Harinck J, Guardone A. Real-gas effects in ORC turbine flow simulations: Influence of thermodynamic models on flow fields and performance parameters. In: Wesseling P, Oñate E, Périaux J, editors. Proceedings of the European Conference on Computational Fluid Dynamics, ECCOMAS CFD 2006, TU Delft, Delft, The Netherlands; 2006. Paper 602.

[28] Saravanamuttoo H I H, Rogers G F C, Cohen H, Straznicky P V. Gas Turbine Theory. 6th ed. Dorset, UK: PEARSON Prentice Hall; 2009. ISBN: 978-0-13-222437-6. 
[29] Pierobon L, Rambabu K, Haglind F. Waste heat recovery for off-shore applications. In: Proceedings of the ASME 2012 International Mechanical Engineering Congress \& Exposition, IMECE2012, November 9-15, Houston, Texas, USA; 2012. Paper 86254.

[30] DOW Chemical Company. Dowtherm Q Heat Transfer Fluid. June 1997.

msdssearch.dow.com/PublishedLiteratureDOWCOM/dh_005f/0901b8038005f2c1.pdf?filepath=heattrans/pdfs/n oreg/176-01467.pdf\&fromPage=GetDoc [Accessed 07/02/2013].

[31] Marler R T, Arora J S. Survey of multi-objective optimization methods for engineering. Structural and Multidisciplinary Optimization 2004; 26(6):369-395.

[32] Falkenauer E. Genetic Algorithms and Grouping Problems. Chichester, UK: John Wiley \& Sons Ltd.; 1997. ISBN 978-0-471-97150-4.

[33] Lemmon W E, Huber L M, McLinden O M. NIST Reference Fluid Thermodynamic and Transport Properties-REFPROP, Version 9.0, User’s guide. Thermophysical Properties Division, National Institute of Standards and Technology, Boulder, Colorado, USA; 2010.

[34] Pierobon L, Nguyen T-V, Larsen U, Haglind F. Optimization of organic Rankine cycles for off-shore applications. In: Proceedings of the ASME Turbo Expo 2013, June 3-7, San Antonio, Texas, USA; 2013. (Final version available online from 27/05/2013).

[35] Lagarias J C, Reeds J A, Wright M H, Wright P E. Convergence Properties of the Nelder-Mead Simplex Method in Low Dimensions. SIAM Journal of Optimization 1998:9(1):112-147. 
[36] Tahseen A T, Ishak M, Rahman M M. A Numerical Study Laminar Forced Convection of Air for In-line Bundle of Cylinders Crossflow. Asian Journal of Scientific Research 2013; 6:217-226.

[37] Bejan A, Tsatsaronis G, Moran M. Thermal Design and Optimization. Canada, John Wiley \& Sons, Inc.; 1995. ISBN 0-471-58467-3.

[38] Index Mundi. Natural Gas Monthly Price - Norwegian Krone per Thousands of cubic meters Apr 2012 - Oct 2012. www.indexmundi.com/commodities/?commodity=natural-gas\&currency=nok [Accessed October 2012].

[39] Lin B, Li X. The effect of carbon tax on per capita $\mathrm{CO}_{2}$ emissions. Energy Policy 2011; 39:5137-5146.

[40] Ministry of the Environment. The Government is following up on the Climate Agreement. Press release, Oslo, Norway, 08.10.2012, www.regjeringen.no/en/dep/md/press-centre/Press-releases/2012/the-government-isfollowing-up-on-the-cl.html?id=704137 [Accessed 07/02/2013].

[41] Rypdal K. Anthropogenic emissions of the greenhouse gases $\mathrm{CO}_{2}, \mathrm{CH}_{4}$ and $\mathrm{N}_{2} \mathrm{O}$ in Norway. Report No.93/24, Oslo, Norway: Central Bureau of Statistics of Norway; 1993. ISBN 82-537-3917-6.

[42] SYSTAT Software Inc. TableCurve 2D v 5.01. www.sigmaplot.com/products/tablecurve2d [Accessed 07/02/2013].

[43] Gonçalves N, Faias S, Sousa de J. Biomass CHP Technical and Economic Assessment applied to a Sawmill Plant. In: Proceedings of the International Conference on Renewable Energies and Power Quality (ICREPQ'12) Santiago de Compostela, Spain, 28-30 March; 2012. Paper 638. 
[44] Ghirardo F, Santin M, Traverso A, Massardo A. Heat recovery options for onboard fuel cell systems. International Journal of Hydrogen Energy 2011; 36:8134-8142.

[45] He M, Zhang X, Zeng K, Gao K. A combined thermodynamic cycle used for waste heat recovery of internal combustion engine. Energy 2011;36:6821-6829.

[46] Lai N A, Wendland M, Fischer J. Working fluids for high-temperature organic Rankine cycles. Energy 2011; 36:199-211.

[47] Ginosar D M, Petkovic L M, Guillen D P. Thermal Stability of Cyclopentane as an Organic Rankine Cycle Working Fluid. Energy \& Fuels 2011; 25:4138-4144.

[48] Wang D, Ling X, Peng H. Performance analysis of double organic Rankine cycle for discontinuous low temperature waste heat recovery. Applied Thermal Engineering 2012; 48:63-71.

[49] Nouman J. Comparative studies and analysis of working fluids for Organic Rankine Cycles - ORC [Master of Science Thesis].KTH School of Industrial Engineering and Management, Stockholm, Sweden; 2012. 